\title{
Abiotic Nitrous Oxide (N2O) Production Is Strongly pH Dependent, but Contributes Little to Overall N2O Emissions in Biological Nitrogen Removal Systems
}

Su, Qingxian; Domingo-Felez, Carlos; Jensen, Marlene Mark; Smets, Barth F.

Published in:

Environmental Science and Technology

Link to article, DOI:

10.1021/acs.est.8b06193

Publication date:

2019

Document Version

Peer reviewed version

Link back to DTU Orbit

Citation (APA):

Su, Q., Domingo-Felez, C., Jensen, M. M., \& Smets, B. F. (2019). Abiotic Nitrous Oxide $\left(\mathrm{N}_{2} \mathrm{O}\right)$ Production Is Strongly pH Dependent, but Contributes Little to Overall $\mathrm{N}_{2} \mathrm{O}$ Emissions in Biological Nitrogen Removal Systems. Environmental Science and Technology, 53(7), 3508-3516. https://doi.org/10.1021/acs.est.8b06193

\section{General rights}

Copyright and moral rights for the publications made accessible in the public portal are retained by the authors and/or other copyright owners and it is a condition of accessing publications that users recognise and abide by the legal requirements associated with these rights.

- Users may download and print one copy of any publication from the public portal for the purpose of private study or research.

- You may not further distribute the material or use it for any profit-making activity or commercial gain

- You may freely distribute the URL identifying the publication in the public portal 
1 Abiotic nitrous oxide $\left(\mathrm{N}_{2} \mathrm{O}\right)$ production is strongly $\mathbf{p H}$ dependent, but

2 contributes little to overall $\mathrm{N}_{2} \mathrm{O}$ emissions in biological nitrogen

3 removal systems

4

5 Qingxian Su, Carlos Domingo-Félez, Marlene M. Jensen, Barth F. Smets*

6

7 Department of Environmental Engineering, Technical University of Denmark, 2800 Lyngby,

8 Denmark

$9 \quad$ * Corresponding author. E-mail: bfsm@env.dtu.dk; Tel: +45 4525 1600; Fax: +45 45932850

10 


\section{ABSTRACT}

Hydroxylamine $\left(\mathrm{NH}_{2} \mathrm{OH}\right)$ and nitrite $\left(\mathrm{NO}_{2}^{-}\right)$, intermediates during the nitritation process, can engage in chemical (abiotic) reactions that lead to nitrous oxide $\left(\mathrm{N}_{2} \mathrm{O}\right)$ generation. Here, we quantify the kinetics and stoichiometry of the relevant abiotic reactions in a series of batch tests under different and relevant conditions, including $\mathrm{pH}$, absence/presence of oxygen, and reactant concentrations. The highest $\mathrm{N}_{2} \mathrm{O}$ production rates were measured from $\mathrm{NH}_{2} \mathrm{OH}$ reaction with $\mathrm{HNO}_{2}$, followed by $\mathrm{HNO}_{2}$ reduction by $\mathrm{Fe}^{2+}, \mathrm{NH}_{2} \mathrm{OH}$ oxidation by $\mathrm{Fe}^{3+}$, and finally $\mathrm{NH}_{2} \mathrm{OH}$ disproportionation plus oxidation by $\mathrm{O}_{2}$. Compared to other examined factors, $\mathrm{pH}$ had the strongest effect on $\mathrm{N}_{2} \mathrm{O}$ formation rates. Acidic $\mathrm{pH}$ enhanced $\mathrm{N}_{2} \mathrm{O}$ production from the reaction of $\mathrm{NH}_{2} \mathrm{OH}$ with $\mathrm{HNO}_{2}$ indicating that $\mathrm{HNO}_{2}$ instead of $\mathrm{NO}_{2}{ }^{-}$was the reactant. In departure from previous studies, we estimate that abiotic $\mathrm{N}_{2} \mathrm{O}$ production contributes little $\left(<3 \%\right.$ of total $\mathrm{N}_{2} \mathrm{O}$ production) to total $\mathrm{N}_{2} \mathrm{O}$ emissions in typical nitritation reactor systems between $\mathrm{pH} 6.5$ and 8 . Abiotic contributions would only become important at acidic $\mathrm{pH}(\leq 5)$. In consideration of $\mathrm{pH}$ effects on both abiotic and biotic $\mathrm{N}_{2} \mathrm{O}$ production pathways, circumneutral $\mathrm{pH}$ set-points are suggested to minimize overall $\mathrm{N}_{2} \mathrm{O}$ emissions from nitritation systems.

Keywords: Nitrous oxide; Abiotic reaction; pH; Nitrous acid; Hydroxylamine 
Rising atmospheric concentrations of nitrous oxide $\left(\mathrm{N}_{2} \mathrm{O}\right)$ contribute to global warming and the destruction of stratospheric ozone ${ }^{1}$. Wastewater treatment plants (WWTPs) are point sources for $\mathrm{N}_{2} \mathrm{O}$ emissions, which are associated with biological nitrogen removal (BNR) ${ }^{2}$. In recent years, BNR processes that involve nitritation (aerobic ammonium $\left(\mathrm{NH}_{4}^{+}\right)$oxidation to nitrite $\left(\mathrm{NO}_{2}^{-}\right)$), anammox (anaerobic $\mathrm{NH}_{4}{ }^{+}$oxidation with $\mathrm{NO}_{2}{ }^{-}$to dinitrogen gas $\left(\mathrm{N}_{2}\right)$ ), or a combination of partial nitritation plus anammox (PNA) are being implemented as energy and resource-efficient alternatives ${ }^{3}$. Compared to traditional nitrification and denitrification, these new BNR processes display lower energy consumption and high resource utilization efficiency ${ }^{4}$. However, the potential for high $\mathrm{N}_{2} \mathrm{O}$ emissions from nitritation reactors may offset the claimed environmental benefits ${ }^{5-9}$. $\mathrm{N}_{2} \mathrm{O}$ emissions are positively associated with characteristics of operational conditions of nitritation systems, such as low dissolved oxygen (DO) and high $\mathrm{NO}_{2}^{-}$concentrations ${ }^{6,10-12}$.

Ammonia oxidizing bacteria $(\mathrm{AOB})$ are considered the major contributors to $\mathrm{N}_{2} \mathrm{O}$ production, especially in nitritation or PNA systems ${ }^{11,13} \cdot \mathrm{N}_{2} \mathrm{O}$ is produced by $\mathrm{AOB}$ as a side product in incomplete oxidation of hydroxylamine $\left(\mathrm{NH}_{2} \mathrm{OH}\right)$ or via the nitrifier denitrification pathway ${ }^{14}$. In addition, during the nitritation processes, reactive intermediates, like $\mathrm{NH}_{2} \mathrm{OH}$, are enzymatically produced. These intermediates may engage in chemical reactions that yield $\mathrm{N}_{2} \mathrm{O}$, especially in the presence of trace metals (e.g. Fe) ${ }^{15}$. In most previous studies on $\mathrm{N}_{2} \mathrm{O}$ production in $\mathrm{BNR}$ reactors, abiotic reactions were ignored or deemed unimportant due to the low environmental concentrations, high reactivity or short life-times of reactive nitrogen intermediates ${ }^{16}$. As these intermediates, especially $\mathrm{NH}_{2} \mathrm{OH}$, are only formed in the presence of microbial activity (and ongoing nitritation); biotic and abiotic processes are tightly linked and their individual contributions are difficult to unravel ${ }^{16}$, as recently highlighted by Soler-Jofra et al. and Terada et al. ${ }^{17-19}$. 
The five dominant chemical reactions that yield $\mathrm{N}_{2} \mathrm{O}$, relevant under environmental conditions of nitritation reactors, are ${ }^{20}$ :

(1) The oxidation of $\mathrm{NH}_{2} \mathrm{OH}$ by $\mathrm{HNO}_{2}{ }^{21}$ :

$$
\mathrm{NH}_{2} \mathrm{OH}+\mathrm{HNO}_{2} \rightarrow \mathrm{N}_{2} \mathrm{O}+2 \mathrm{H}_{2} \mathrm{O}
$$

(2) The oxidation of $\mathrm{NH}_{2} \mathrm{OH}$ by $\mathrm{O}_{2}{ }^{22}$ :

$$
2 \mathrm{NH}_{2} \mathrm{OH}+\mathrm{O}_{2} \rightarrow \mathrm{N}_{2} \mathrm{O}+3 \mathrm{H}_{2} \mathrm{O}
$$

(3) The disproportionation of $\mathrm{NH}_{2} \mathrm{OH}^{23}$ :

$$
4 \mathrm{NH}_{2} \mathrm{OH} \rightarrow 2 \mathrm{NH}_{3}+\mathrm{N}_{2} \mathrm{O}+3 \mathrm{H}_{2} \mathrm{O}
$$

(4) The reduction of $\mathrm{HNO}_{2}$ by $\mathrm{Fe}^{2+24}$ :

$$
2 \mathrm{HNO}_{2}+4 \mathrm{Fe}^{2+}+4 \mathrm{H}^{+} \rightarrow 4 \mathrm{Fe}^{3+}+\mathrm{N}_{2} \mathrm{O}+3 \mathrm{H}_{2} \mathrm{O}
$$

(5) The oxidation of $\mathrm{NH}_{2} \mathrm{OH}$ by $\mathrm{Fe}^{3+25}$ :

$$
4 \mathrm{Fe}^{3+}+2 \mathrm{NH}_{2} \mathrm{OH} \rightarrow 4 \mathrm{Fe}^{2+}+\mathrm{N}_{2} \mathrm{O}+\mathrm{H}_{2} \mathrm{O}+4 \mathrm{H}^{+}
$$

Factors known to regulate biological $\mathrm{N}_{2} \mathrm{O}$ production, like $\mathrm{pH}$ and reactant availability, would also affect abiotic $\mathrm{N}_{2} \mathrm{O}$ production rates. $\mathrm{pH}$ would influence the speciation of several reactants $\left(\mathrm{HNO}_{2}\right.$, $\mathrm{NH}_{2} \mathrm{OH}, \mathrm{Fe}^{2+} / \mathrm{Fe}^{3+}$ ), and acidic $\mathrm{pH}$ has been suggested to enhance abiotic $\mathrm{N}_{2} \mathrm{O}$ emissions ${ }^{17,18,24,26}$. However, the rates of the abiotic $\mathrm{N}_{2} \mathrm{O}$ yielding reactions are poorly investigated, and hence their contributions to total (biotic + abiotic) $\mathrm{N}_{2} \mathrm{O}$ production are highly uncertain ${ }^{20}$. Reports on abiotic $\mathrm{N}_{2} \mathrm{O}$ production rates vary widely and the comparison between studies is difficult $18,19,24,26,27$. For instance, the $\mathrm{N}_{2} \mathrm{O}$ emissions rates through abiotic reaction of $\mathrm{NH}_{2} \mathrm{OH}$ with $\mathrm{NO}_{2}{ }^{-}$were estimated at $0.0057 \mathrm{mM} / \mathrm{h}(\mathrm{pH}=7)$ under conditions similar to those observed in a SHARON reactor (i.e., without biomass but at consistent $\mathrm{NH}_{2} \mathrm{OH}$ and $\mathrm{NO}_{2}{ }^{-}$concentrations of $0.02 \mathrm{mM}$ and $46.4 \mathrm{mM}$, respectively) ${ }^{18}$, while others measured 10 - to 100 -fold higher abiotic $\mathrm{N}_{2} \mathrm{O}$ production rates of 0.05 $0.9 \mathrm{mM} / \mathrm{h}(\mathrm{pH}=7)$ in the presence and absence of AOB-enriched biomass (at $\mathrm{NH}_{2} \mathrm{OH}$ and $\mathrm{NO}_{2}{ }^{-}$ concentrations of 0.07-1.4 mM and $28.6 \mathrm{mM}$, respectively) ${ }^{19}$. Additionally, kinetic parameters of 
abiotic reactions were not estimated in previous abiotic studies on nitritation systems due to incomplete data point under limited range of experimental conditions ${ }^{17-19,27}$. To better assess the contribution of abiotic reactions to $\mathrm{N}_{2} \mathrm{O}$ emissions, nitrogen mass balance and reaction rate constants $(k)$ should developed.

The main objectives of this study were, therefore, to carefully examine $\mathrm{N}_{2} \mathrm{O}$ production rates of relevant abiotic reactions (Eq.1-5) and infer reaction kinetics, in the absence of biological reactions and with specific attention to the effect of $\mathrm{pH}$ (4-9). Using the estimated reaction rate kinetics, we assessed the contribution of abiotic reactions to overall $\mathrm{N}_{2} \mathrm{O}$ emissions from nitritation processes as studied by us and others $18,19,27$. Overall, we conclude that the quantitative contribution of abiotic reactions to $\mathrm{N}_{2} \mathrm{O}$ production under nitritation reactor conditions is smaller than previously estimated.

\section{MATERIALS AND METHODS}

\section{Experiments}

Conditions similar to those encountered in biological nitritation reactors were applied in batch tests (without biomass) to assess $\mathrm{N}_{2} \mathrm{O}$ production rates through a series of chemical reactions (Supporting Information (SI), Table S1). Abiotic batch tests were conducted in a jacketed glass vessel with working volume of $0.4 \mathrm{~L}$ at room temperature $\left(24-26^{\circ} \mathrm{C}\right)$ under high DO $(8-8.4 \mathrm{mg} \mathrm{O} / \mathrm{L})$ or low DO $\left(<1 \mathrm{mg} \mathrm{O}_{2} / \mathrm{L}\right)$ conditions. To examine the effect of reactor medium on $\mathrm{N}_{2} \mathrm{O}$ production, we performed experiments in deionized water $\left(\mathrm{diH}_{2} \mathrm{O}\right)$ as well as in a typical synthetic medium in nitrification studies ${ }^{28}$. The synthetic medium consisted of $169.7 \mathrm{mg} / \mathrm{L} \mathrm{KH}_{2} \mathrm{PO} 4,751.1 \mathrm{mg} / \mathrm{L}$ $\mathrm{MgSO} 4 \cdot 7 \mathrm{H}_{2} \mathrm{O}, 451.6 \mathrm{mg} / \mathrm{L} \mathrm{CaCl} 2 \cdot 2 \mathrm{H}_{2} \mathrm{O}, 5 \mathrm{mg} / \mathrm{L}$ EDTA, $5 \mathrm{mg} / \mathrm{L} \mathrm{FeSO}_{4} \cdot 7 \mathrm{H}_{2} \mathrm{O}$ and a trace element solution including $0.43 \mathrm{mg} / \mathrm{L} \mathrm{ZnSO} \cdot 7 \mathrm{H}_{2} \mathrm{O}, 0.24 \mathrm{mg} / \mathrm{L} \mathrm{CoCl}_{2} \cdot 6 \mathrm{H}_{2} \mathrm{O}, 0.99 \mathrm{mg} / \mathrm{L} \mathrm{MnCl} \mathrm{Mn}_{2} \cdot 4 \mathrm{H}_{2} \mathrm{O}, 0.25$ $\mathrm{mg} / \mathrm{L} \quad \mathrm{CuSO}_{4} \cdot 5 \mathrm{H}_{2} \mathrm{O}, \quad 0.22 \mathrm{mg} / \mathrm{L} \quad \mathrm{NaMoO}_{4} \cdot 2 \mathrm{H}_{2} \mathrm{O}, \quad 0.19 \mathrm{mg} / \mathrm{L} \quad \mathrm{NiCl}_{2} \cdot 6 \mathrm{H}_{2} \mathrm{O}$ and $0.21 \mathrm{mg} / \mathrm{L}$ $\mathrm{NaSeO}_{4} \cdot 10 \mathrm{H}_{2} \mathrm{O}{ }^{29}$. The $\mathrm{diH}_{2} \mathrm{O}$ or medium was saturated with nitrogen gas or air, and adjusted to 
target $\mathrm{pH}$ before each test. The vessel was completely filled with $\mathrm{diH}_{2} \mathrm{O}$ or medium and sealed with the insertion of sensors and rubber stoppers. Substrates were then spiked into the vessel to initiate abiotic reactions after sensor signals had stabilized. Samples were collected periodically for chemical analysis (i.e. $\mathrm{NO}_{2}{ }^{-}, \mathrm{NH}_{2} \mathrm{OH}, \mathrm{Fe}^{2+}$ and $\mathrm{Fe}^{3+}$ ). The headspace in the vessel increased (from 0 L) to maximum $0.022 \mathrm{~L}$ at the end of the experiment. During experiments, $\mathrm{pH}$ was controlled by manually adding $0.5 \mathrm{M} \mathrm{HCl}$ and $0.5 \mathrm{M} \mathrm{NaHCO}_{3}$, and continuous mixing was provided with a magnetic stirrer at $100 \mathrm{rpm}$.

Two experimental scenarios were used: in Scenario 1, we performed parallel tests at fixed initial $\mathrm{pH}$ $\left(\mathrm{pH}=4,5,6,7,8\right.$ and 9) and fixed initial substrate concentrations $\left(17.8 \mathrm{mM} \mathrm{NO}_{2}^{-}, 0.07 \mathrm{mM}\right.$ $\mathrm{NH}_{2} \mathrm{OH}, 0.5 \mathrm{mM} \mathrm{FeSO}$ and $0.1 \mathrm{mM} \mathrm{FeCl}_{3}$ ); in Scenario 2, we performed tests with certain initial concentrations that were subject to stepwise changes (increase in reactants, decrease in $\mathrm{pH}$ ) by sequential spiking of reactants and acid. Further experimental details are listed in SI Table S1.

\section{Offline chemical analysis and $\mathrm{pH}, \mathrm{DO}$ and $\mathrm{N}_{2} \mathrm{O}$ monitoring}

Abiotic tests were conducted without biomass in deionized water or the synthetic medium. $\mathrm{NO}_{2}^{-}$ concentrations were analyzed colorimetrically by Merck kits. $\mathrm{NH}_{2} \mathrm{OH}$ was determined spectrophotometrically ${ }^{30}$ and sulfamic acid was added immediately after sampling to prevent the reaction of $\mathrm{NH}_{2} \mathrm{OH}$ with $\mathrm{NO}_{2}^{-}$(SI Section 1). The modified ferrozine method was applied to sequentially determine concentrations of $\mathrm{Fe}^{2+}$ and $\mathrm{Fe}^{3+}$, where $\mathrm{Fe}^{3+}$ is reduced to $\mathrm{Fe}^{2+}$ by $\mathrm{NH}_{2} \mathrm{OH}$ under strongly acidic conditions ${ }^{31} \cdot \mathrm{pH}$ and DO were monitored continuously (WTW GmbH,

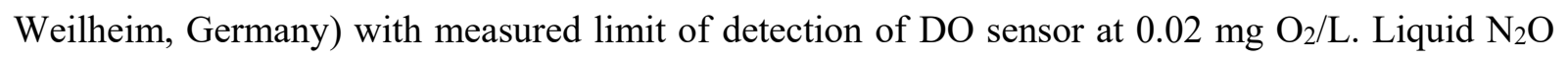
was measured online by $\mathrm{N}_{2} \mathrm{O}-\mathrm{R}$ Clark-type microsensors (UNISENSE A/S, Århus, Denmark) with limit of detection of $0.1 \mu \mathrm{M}$ and data logged every $30 \mathrm{~s}$. The $\mathrm{pH}$ sensitivity of the $\mathrm{N}_{2} \mathrm{O}$ sensor was measured below $0.2 \%$ of the signal, and neither DO levels nor stirring intensity interfered with the 
signal (SI Section 2). The response times of $\mathrm{N}_{2} \mathrm{O}, \mathrm{pH}$, and DO sensors were $<30 \mathrm{~s}, \leq 45 \mathrm{~s}$, and $\leq 45 \mathrm{~s}$, respectively.

\section{Calculations}

Free nitrous acid (FNA) concentrations (mM) were calculated as:

$\mathrm{HNO}_{2}=\frac{10^{-\mathrm{pH}} \cdot\left[\mathrm{NO}_{2}^{-}-\mathrm{N}\right]}{14 \cdot 10^{-\mathrm{pK}_{\mathrm{a}}}}$

Where $\mathrm{pK}_{\mathrm{a}}$ is the dissociation equilibrium constant of $\mathrm{HNO}_{2}$ corrected for temperature $(\mathrm{pK} a(\mathrm{~T})=$ $\mathrm{pK}_{\mathrm{a}}(298)+0.0324(\mathrm{~T}-298)\left(\mathrm{pK}_{\mathrm{a}} 3.25\right.$ at $\left.\left.298 \mathrm{~K}\right)\right)$. The $\mathrm{NH}_{2} \mathrm{OH}$ depletion rate $\left(\mathrm{r}_{\mathrm{NH}} \mathrm{OH}\right)$, the $\mathrm{Fe}^{2+}$ depletion rate $\left(\mathrm{r}_{\mathrm{Fe} 2+}\right)$ and the $\mathrm{N}_{2} \mathrm{O}$ production rate $\left(\mathrm{r}_{\mathrm{N} 2 \mathrm{O}}\right)(\mathrm{mM} / \mathrm{min}$ or $\mathrm{mM} / \mathrm{h})$ were estimated from the slope of the measured concentration profiles of $\mathrm{Fe}^{2+}, \mathrm{NH}_{2} \mathrm{OH}$ and $\mathrm{N}_{2} \mathrm{O}(\mathrm{mM})(\mathrm{n}>3)$, respectively. The total amount of $\mathrm{NH}_{2} \mathrm{OH}\left(\mathrm{mNH}_{2} \mathrm{OH}, \mathrm{mmol}\right)$ or $\mathrm{Fe}^{2+}$ consumed $\left(\mathrm{mFe}_{2}+, \mathrm{mmol}\right)$ and $\mathrm{N}_{2} \mathrm{O}$ produced $(\mathrm{m} N 2 \mathrm{O}, \mathrm{mmol})$ were calculated through integration of the depletion/production profiles multiplied by the working volume of the vessel $(0.4 \mathrm{~L})$. The total $\mathrm{N}_{2} \mathrm{O}$ production could be calculated based on liquid phase measurements because the liquid-gas transfer of $\mathrm{N}_{2} \mathrm{O}$ was minimal due to low stirring intensity and the low head-space volume (0.022 L maximum). Based on Henry's law, the maximum $\left[\mathrm{N}_{2} \mathrm{O}_{\text {gaseous }}\right]:\left[\mathrm{N}_{2} \mathrm{O}_{\text {liquid }}\right]$ molar ratio was $1: 419\left(\mathrm{H}=0.025 \mathrm{M} / \mathrm{atm}\right.$ at $\left.25^{\circ} \mathrm{C}^{32}\right)$, resulting in maximum $0.2 \%$ of $\mathrm{N}_{2} \mathrm{O}$ partitioned in the gaseous phase. The $\mathrm{r}_{2} \mathrm{O}$ and $\mathrm{m}_{\mathrm{N} 2 \mathrm{O}}$ of $\mathrm{NH}_{2} \mathrm{OH}$ oxidation by $\mathrm{HNO}_{2}$ and $\mathrm{Fe}^{3+}$, respectively, were estimated after correction by subtraction of $\mathrm{N}_{2} \mathrm{O}$ production by $\mathrm{NH}_{2} \mathrm{OH}$ disproportionation and/or oxidation by $\mathrm{O}_{2}$, since we assume that the latter reactions co-occur simultaneously with other reactions (Table S2). The $\mathrm{N}_{2} \mathrm{O}$ yield relative to the amount of $\mathrm{NH}_{2} \mathrm{OH}$ or

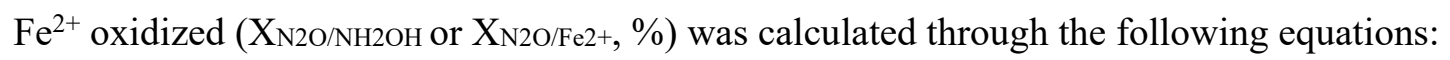

The oxidation of $\mathrm{NH}_{2} \mathrm{OH}$ by $\mathrm{HNO}_{2}$ :

$\mathrm{X}_{\mathrm{N}_{2} \mathrm{O} / \mathrm{NH}_{2} \mathrm{OH}}=\frac{\mathrm{m}_{\mathrm{N}_{2} \mathrm{O}}}{\mathrm{m}_{\mathrm{NH}_{2} \mathrm{OH}}} \cdot 100 \%$

The oxidation of $\mathrm{NH}_{2} \mathrm{OH}$ by $\mathrm{O}_{2}$ : 
$146 \quad \mathrm{X}_{\mathrm{N}_{2} \mathrm{O} / \mathrm{NH}_{2} \mathrm{OH}}=\frac{\mathrm{m}_{\mathrm{N}_{2} \mathrm{O}} \cdot 2}{\mathrm{~m}_{\mathrm{NH}_{2} \mathrm{OH}}} \cdot 100 \%$

147 The disproportionation of $\mathrm{NH}_{2} \mathrm{OH}$ :

$148 \quad \mathrm{X}_{\mathrm{N}_{2} \mathrm{O} / \mathrm{NH}_{2} \mathrm{OH}}=\frac{\mathrm{m}_{\mathrm{N}_{2} \mathrm{O}} \cdot 4}{\mathrm{~m}_{\mathrm{NH}_{2} \mathrm{OH}}} \cdot 100 \%$

149 The reduction of $\mathrm{HNO}_{2}$ by $\mathrm{Fe}^{2+}$ :

$150 \quad \mathrm{X}_{\mathrm{N}_{2} \mathrm{O} / \mathrm{Fe}^{2+}}=\frac{\mathrm{m}_{\mathrm{N}_{2} \mathrm{O}} \cdot 4}{\mathrm{~m}_{\mathrm{Fe}^{2+}}} \cdot 100 \%$

151 The oxidation of $\mathrm{NH}_{2} \mathrm{OH}$ by $\mathrm{Fe}^{3+}$ :

$152 \quad \mathrm{X}_{\mathrm{N}_{2} \mathrm{O} / \mathrm{NH}_{2} \mathrm{OH}}=\frac{\mathrm{m}_{\mathrm{N}_{2} \mathrm{O}} \cdot 2}{\mathrm{~m}_{\mathrm{NH}_{2} \mathrm{OH}}} \cdot 100 \%$

153 Assuming elementary reaction kinetics and stoichiometry as expressed in Eq.1-5, we estimated $\mathrm{N}_{2} \mathrm{O}$

154 production rate constants using the following rate equations for the different reactions:

155 The disproportionation of $\mathrm{NH}_{2} \mathrm{OH}$ :

$156 \mathrm{r}_{\mathrm{N} 2 \mathrm{O}}=k_{1} \cdot\left[\mathrm{NH}_{2} \mathrm{OH}\right]^{4}$

157 The oxidation of $\mathrm{NH}_{2} \mathrm{OH}$ by $\mathrm{O}_{2}$ :

$158 \quad \mathrm{r}_{\mathrm{N} 2 \mathrm{O}}=k_{2} \cdot\left[\mathrm{NH}_{2} \mathrm{OH}\right]^{2}$

159 The oxidation of $\mathrm{NH}_{2} \mathrm{OH}$ by $\mathrm{HNO}_{2}$ :

$160 \mathrm{rN}_{\mathrm{N} 2}=k_{3} \cdot\left[\mathrm{HNO}_{2}\right] \cdot\left[\mathrm{NH}_{2} \mathrm{OH}\right]$

161 Estimates for reaction rate constants $\left(\mathrm{L} / \mathrm{mmol} / \mathrm{h}\right.$ or $\left.\mathrm{L}^{3} / \mathrm{mmol}^{3} / \mathrm{h}\right)$ were obtained by fitting 162 experimental data to Eq.12-14 by minimizing the normalized root mean square error (NRMSE).

163 The correlation between reaction rate constants and $\mathrm{pH}$ was achieved by nonlinear regression fitting. 164 The best-fit values were found with the solver function in Excel. Data reported in the literature 165 17,18,24,26,27 were extracted using WebPlotDigitizer (https://apps.automeris.io/wpd/), and processed 166 mathematically as mentioned above. 


\section{RESULTS}

\section{$\mathrm{NH}_{2} \mathrm{OH}$ disproportionation and/or oxidation by $\mathrm{O}_{2}$}

After the addition of $\mathrm{NH}_{2} \mathrm{OH}$ solution to $\mathrm{diH}_{2} \mathrm{O}$ or medium, both $\mathrm{NH}_{2} \mathrm{OH}$ depletion and $\mathrm{N}_{2} \mathrm{O}$ production were continuously monitored (SI Figure S1). At initial $\mathrm{NH}_{2} \mathrm{OH}$ concentration of 0.07 $\mathrm{mM}$, the maximum $\mathrm{rNH}_{2} \mathrm{OH}(0.0073 \mathrm{mM} / \mathrm{h})$ and $\mathrm{r}_{\mathrm{N} 2 \mathrm{O}}(0.0020 \mathrm{mM} / \mathrm{h})$ occurred at $\mathrm{pH}=8$ in synthetic medium under high DO conditions (Scenario 1) (Figure 1, SI Figure S1, Table S4). $\mathrm{r}_{\mathrm{NH} 2 \mathrm{OH}}$ and $\mathrm{r}_{\mathrm{N} 2 \mathrm{O}}$ in synthetic medium were 2-22 times higher than in $\mathrm{diH}_{2} \mathrm{O}$, indicating that trace concentrations of dissolved metals (e.g. $\mathrm{Fe}^{2+} / \mathrm{Fe}^{3+}, \mathrm{Cu}^{2+}, \mathrm{Mn}^{2+}$ ) accelerated $\mathrm{NH}_{2} \mathrm{OH}$ decomposition to $\mathrm{N}_{2} \mathrm{O}$, either by direct participation as reactants or by acting as catalysts ${ }^{22,33-35}$. While it is not possible to isolate $\mathrm{NH}_{2} \mathrm{OH}$ disproportionation from $\mathrm{NH}_{2} \mathrm{OH}$ oxidation by $\mathrm{O}_{2}$ under the examined DO conditions, $\mathrm{O}_{2}$ had a limited stimulatory effect on $\mathrm{N}_{2} \mathrm{O}$ production both in $\mathrm{diH}_{2} \mathrm{O}$ or synthetic medium (Figure 1-A).

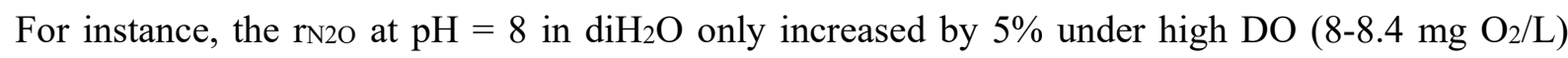
compared to that under low DO $(<1 \mathrm{mg} \mathrm{O} / \mathrm{L})$ (Figure 1). Furthermore, the $\mathrm{N}_{2} \mathrm{O}$ yield (relative to the amount of $\mathrm{NH}_{2} \mathrm{OH}$ oxidized) calculated following Eq. 8 and 9 was $41 \pm 14 \%$ (data not shown) and $82 \pm 28 \%$ (Figure 1-C), respectively, indicating that the reactions followed the stoichiometry of $\mathrm{NH}_{2} \mathrm{OH}$ disproportionation. Hence, $\mathrm{NH}_{2} \mathrm{OH}$ disproportionation was more important than $\mathrm{NH}_{2} \mathrm{OH}$ oxidation by $\mathrm{O}_{2}$. Further measurements of $\mathrm{NH}_{4}{ }^{+}$production from $\mathrm{NH}_{2} \mathrm{OH}$ disproportionation (Eq.3) would help to separate these two reactions. The $\mathrm{N}_{2} \mathrm{O}$ yield relative to the amount of $\mathrm{NH}_{2} \mathrm{OH}$ did not vary substantially with $\mathrm{pH}($ Figure $1-\mathrm{C})$.

\section{$\mathrm{NH}_{2} \mathrm{OH}$ oxidation by $\mathrm{HNO}_{2}$}

The reaction of $\mathrm{NH}_{2} \mathrm{OH}$ with $\mathrm{HNO}_{2}$ was followed by adding $\mathrm{NO}_{2}^{-}$to the vessel with an initial $\mathrm{NH}_{2} \mathrm{OH}$ concentration of $0.07 \mathrm{mM}$ (Scenario 1). $\mathrm{NH}_{2} \mathrm{OH}$ was depleted at a rate of $0.00022-0.39$ $\mathrm{mM} / \mathrm{h}$ after addition of $\mathrm{NO}_{2}{ }^{-}$, with a strong dependency on the $\mathrm{HNO}_{2}$ concentration (Figure 2). At excess $\mathrm{NO}_{2}{ }^{-}$concentrations $(\geq 13.0 \mathrm{mM}), \mathrm{HNO}_{2}$ concentrations ranged from 0.0002 to $0.9 \mathrm{mM}$ 
depending on $\mathrm{pH}(4.5-8) . \mathrm{HNO}_{2}$ concentrations remained nearly constant and were unlikely to limit the reaction. $\mathrm{N}_{2} \mathrm{O}$ production initiated when both $\mathrm{NH}_{2} \mathrm{OH}$ and $\mathrm{NO}_{2}^{-}$were spiked, and ceased with depletion of $\mathrm{NH}_{2} \mathrm{OH}$ (Figure 2). The $\mathrm{r}_{\mathrm{N} 2 \mathrm{O}}$ ranged from 0.00014 to $0.78 \mathrm{mM} / \mathrm{h}$ at different $\mathrm{pH}$ setpoints, DO levels and medium types (Figure 3-A). Assuming elementary reaction kinetics (Eq.1), based on the measured $\mathrm{NH}_{2} \mathrm{OH}$ and $\mathrm{HNO}_{2}$ concentrations, $k$ values were estimated in the range of 0.92-56 L/mmol/h, with higher rates at lower $\mathrm{pH}$ (Figure 3-A).

pH significantly affected $\mathrm{N}_{2} \mathrm{O}$ formation: the $\mathrm{N}_{2} \mathrm{O}$ production rate increased four orders of magnitude, with a consistent (almost four log) decrease in $\mathrm{pH}$ (Scenario 1) (Figure 3-A). Also, in the sequential acid addition (Scenario 2), sequential $\mathrm{pH}$ drops led to a rapid $\mathrm{N}_{2} \mathrm{O}$ production, with $\mathrm{r}_{\mathrm{N} 2 \mathrm{O}}$ at $\mathrm{pH}=6$ being more than two orders of magnitude higher than at $\mathrm{pH}=8.5$ (Figure 2-B). The results indicate that $\mathrm{HNO}_{2}$ instead of $\mathrm{NO}_{2}{ }^{-}$is the actual reactant. Expressing the reaction rate as a function of $\mathrm{HNO}_{2}$ showed that the reaction rate constant increased slightly with $\mathrm{pH}$ decrease $(k=$ 8272.5 $\mathrm{e}^{-1.1 \mathrm{pH}}, \mathrm{R}^{2}=0.99$; Figure 3-A). Similar to $\mathrm{rN}_{\mathrm{N}} \mathrm{O}, \mathrm{r} \mathrm{NH} 2 \mathrm{OH}$ significantly increased with decreasing $\mathrm{pH}$, which was $\sim 400$ times higher at $\mathrm{pH}=4.5$ than at $\mathrm{pH}=8$ (Figure 3-B). Presence/absence of oxygen or medium type had limited effect on either $\mathrm{NH}_{2} \mathrm{OH}$ depletion or $\mathrm{N}_{2} \mathrm{O}$ formation. The influence of the reactant $\left(\mathrm{NH}_{2} \mathrm{OH} / \mathrm{HNO}_{2}\right)$ concentration on the reaction kinetics was outweighed by the $\mathrm{pH}$ effect (Figure 2-B). The $\mathrm{N}_{2} \mathrm{O}$ yield (relative to the amount of $\mathrm{NH}_{2} \mathrm{OH}$ oxidized) increased from $35 \%$ at $\mathrm{pH}=8$ to nearly $200 \%$ at $\mathrm{pH}=4.5$, suggesting different reaction mechanisms (Figure 3-C).

\section{Iron-mediated reduction of $\mathrm{HNO}_{2}$}

211 After $\mathrm{NO}_{2}{ }^{-}$addition, $\mathrm{Fe}^{2+}$ was oxidized to $\mathrm{Fe}^{3+}$ at a constant rate coupled with $\mathrm{N}_{2} \mathrm{O}$ production. $\mathrm{Fe}^{2+}$

212 was depleted at a rate of $0.28 \pm 0.04 \mathrm{mM} / \mathrm{h}$, while $\mathrm{Fe}^{3+}$ accumulated at a nearly equimolecular rate 213 of $0.29 \pm 0.02 \mathrm{mM} / \mathrm{h}(\mathrm{pH}=4.5)\left(\right.$ Eq.4) (Scenario 1) (SI Figure S2-A). The $\mathrm{r}_{\mathrm{Fe} 2}+$ was two-fold higher 214 than $\mathrm{r}_{\mathrm{N} 2 \mathrm{O}}$ and $\mathrm{N}_{2} \mathrm{O}$ yield relative to the amount of oxidized $\mathrm{Fe}^{2+}$ was up to $100 \%$, indicating that 
$215 \mathrm{Fe}^{2+}$ reacted with $\mathrm{HNO}_{2}$ following the stoichiometry of Eq.4 (SI Figure S3). However, at $\mathrm{pH}=6$

216 and 8 , the ratio between $\mathrm{rFe}_{2}+$ and $\mathrm{r}_{\mathrm{Fe} 3}+$ was higher than $1: 1$ (data not shown), and the $\mathrm{N}_{2} \mathrm{O}$ yields

217 from oxidized $\mathrm{Fe}^{2+}$ were lower than $50 \%$. This is likely due to $\mathrm{Fe}^{2+}$ oxidation by $\mathrm{O}_{2}(0.02-0.5 \mathrm{mg}$

$218 \mathrm{O}_{2} / \mathrm{L}$ ) to form $\mathrm{Fe}^{3+}$ as precipitate and oxyhydroxide or $\mathrm{Fe}^{2+}$ oxidation coupled with $\mathrm{HNO}_{2}$ reduction

219 to ammonium, which can occur under neutral or alkaline $\mathrm{pH}^{36}$. Both $\mathrm{r}_{\mathrm{Fe} 2+}$ and $\mathrm{r}_{\mathrm{N} 2 \mathrm{O}}$ were strongly

220 dependent on $\mathrm{pH}$ but not on $\mathrm{Fe}^{2+}$ or $\mathrm{NO}_{2}^{-}: \mathrm{Fe}^{2+}$ depletion and $\mathrm{N}_{2} \mathrm{O}$ production increased steeply

221 when $\mathrm{HCl}$ was spiked into the vessel and there were less significant responses to increasing

222 concentrations of $\mathrm{NO}_{2}^{-}$and $\mathrm{Fe}^{2+}$ (SI Figure $\left.\mathrm{S} 2-\mathrm{B}\right)$.

$223 \mathrm{NH}_{2} \mathrm{OH}$ oxidation by $\mathrm{Fe}^{3+}$

224 The reaction of $\mathrm{Fe}^{3+}$ with $\mathrm{NH}_{2} \mathrm{OH}$ was only tested under $\mathrm{pH}=4.3$ due to the formation of 225 precipitates and iron oxyhydroxide species at alkaline $\mathrm{pH}$, which would have resulted in lower rates 226 (Scenario 1). $\mathrm{NH}_{2} \mathrm{OH}$ and $\mathrm{Fe}^{3+}$ were depleted at rates of 0.003 and $0.005 \mathrm{mM} / \mathrm{h}$, respectively, 227 resulting in production rates of $\mathrm{N}_{2} \mathrm{O}$ and $\mathrm{Fe}^{2+}$ of 0.001 and $0.005 \mathrm{mM} / \mathrm{h}$, respectively (SI Figure S4). 228 The reacted $\mathrm{Fe}^{3+}$ and $\mathrm{NH}_{2} \mathrm{OH}$ followed the stoichiometry of Eq.5. The $\mathrm{N}_{2} \mathrm{O}$ yield relative to the amount of $\mathrm{NH}_{2} \mathrm{OH}$ oxidized was $66 \%$ at $\mathrm{pH}=4.3$.

\section{DISCUSSION}

\section{$\mathrm{pH}$ as the key factor influencing abiotic $\mathrm{N}_{2} \mathrm{O}$ production rates}

$\mathrm{pH}$ has a significant effect on abiotic $\mathrm{N}_{2} \mathrm{O}$ reaction kinetics in the range studied $(\mathrm{pH}=4-9)$ in the presence of $\mathrm{HNO}_{2}, \mathrm{NH}_{2} \mathrm{OH}$ and iron $\left(\mathrm{Fe}^{2+}\right.$ and $\mathrm{Fe}^{3+}$ ) (Figure 1-3, SI Figure $\left.\mathrm{S} 1-4\right) \cdot \mathrm{pH}$ is known to change the speciation of $\mathrm{NO}_{2}^{-}$(by equilibrium with $\mathrm{HNO}_{2}$ ), $\mathrm{NH}_{2} \mathrm{OH}$ (by equilibrium with $\mathrm{NH}_{3} \mathrm{OH}^{+}$) and iron (by formation of different precipitates and iron oxyhydroxide species). Previous abiotic

$\mathrm{N}_{2} \mathrm{O}$ studies in nitritation systems could not elucidate whether $\mathrm{NO}_{2}^{-}$or $\mathrm{HNO}_{2}$ was the actual 
oxidation was limited by the concentration of $\mathrm{HNO}_{2}{ }^{18}$, whereas others regarded $\mathrm{NO}_{2}^{-}$as the reactant ${ }^{19,24,27}$. In our experiments, stepwise dosing of $\mathrm{NO}_{2}{ }^{-}$at constant $\mathrm{pH}$ did not stimulate $\mathrm{N}_{2} \mathrm{O}$ yield significantly, while sharp $\mathrm{N}_{2} \mathrm{O}$ peaks were observed after $\mathrm{pH}$ drops that shifted the $\mathrm{NO}_{2}^{-}$ speciation to $\mathrm{HNO}_{2}$ (Figure 2-B), indicating $\mathrm{HNO}_{2}$ instead of $\mathrm{NO}_{2}^{-}$as the actual reactant. Combined with the observed dependence of the reaction rate constant on $\mathrm{pH}\left(k=8272.5 \mathrm{e}^{-1.1 \mathrm{pH}}, \mathrm{R}^{2}=0.99\right)$, acidic $\mathrm{pH}$ enhances $\mathrm{N}_{2} \mathrm{O}$ production both by an increase in reaction rate constant and $\mathrm{HNO}_{2}$ speciation. With respect to $\mathrm{NH}_{2} \mathrm{OH}$ disproportionation and oxidation by $\mathrm{O}_{2}$, higher $\mathrm{NH}_{2} \mathrm{OH}$ depletion rates and $\mathrm{N}_{2} \mathrm{O}$ production rates were achieved at higher $\mathrm{pH}$.

$\mathrm{pH}$ also affects the product conversion ratios of chemical reactions (Figure 3-C). We observed a conversion of $35 \pm 9 \%$ and $174 \pm 19 \%$ of oxidized $\mathrm{NH}_{2} \mathrm{OH}$ into $\mathrm{N}_{2} \mathrm{O}$ at $\mathrm{pH} \geq 7$ and at $\mathrm{pH}<7$, respectively, indicating that side reactions may occur at different $\mathrm{pH}$ levels. The low recovery of $\mathrm{N}_{2} \mathrm{O}$ at $\mathrm{pH} \geq 7$ was in agreement with findings by Soler-Jofra et al. $(2018,2016)$, in which the conversion ratio of $\mathrm{NH}_{2} \mathrm{OH}$ to $\mathrm{N}_{2} \mathrm{O}$ ranged from $20 \pm 1 \%$ to $40 \pm 2 \%$ at $\mathrm{pH}=7.5 \pm 0.1^{17,18}$. The authors attributed this to the presence of a side reaction between $\mathrm{NH}_{2} \mathrm{OH}$ and $\mathrm{HNO}$ (the monomer of hyponitrous acid, one intermediate of reaction Eq.1) with $\mathrm{N}_{2}$ as the final product. The higher recovery of $\mathrm{N}_{2} \mathrm{O}$ over theoretical value $(100 \%)$ at acidic $\mathrm{pH}$ has not been reported. Since $\mathrm{NH}_{2} \mathrm{OH}$ was completely oxidized at the end of experiments, the gap in the nitrogen mass balances cannot be explained by equimolecular use of $\mathrm{NH}_{2} \mathrm{OH}$ and $\mathrm{HNO}_{2}$. Yet, $\mathrm{N}_{2} \mathrm{O}$ could not be detected in the sole presence of $\mathrm{HNO}_{2}$ (data not shown). The recovered excess $\mathrm{N}_{2} \mathrm{O}$ is suspected to be due to a higher stoichiometry in $\mathrm{HNO}_{2}$, which has been reported to increase above 1 and can approach 2 under acidic conditions $(\mathrm{pH}=2)^{37}$. Transient $\mathrm{N}_{2} \mathrm{O}$ peaks were observed immediately after acid additions (Figure 2-B), making it difficult to estimate $\mathrm{r}_{\mathrm{N} 2 \mathrm{O}}$. Considering low sensitivities of the $\mathrm{N}_{2} \mathrm{O}$ sensor towards changes in $\mathrm{pH}$, oxygen and stirring intensity (SI Section 2), the observation of transient $\mathrm{N}_{2} \mathrm{O}$ peaks is unlikely caused by uneven mixing, a transient response of the $\mathrm{N}_{2} \mathrm{O}$ sensor, or signal 
interference by $\mathrm{pH}$ changes. The determination of abiotic $\mathrm{N}_{2} \mathrm{O}$ production rates during sequential acid additions would require further investigation.

264

265

\section{Reaction mechanisms and proposed reaction kinetics}

The kinetics and mechanisms of the oxidation of $\mathrm{NH}_{2} \mathrm{OH}$ by $\mathrm{HNO}_{2}$ have been investigated under acidic conditions down to $\mathrm{pH}=1^{37-41}$. The reaction is believed to occur by an initial O-nitrosation, which leads to the formation of $\mathrm{ON} \cdot \mathrm{NH}_{2} \cdot \mathrm{OH}^{+}{ }^{37}$. Then $\mathrm{ON} \cdot \mathrm{NH}_{2} \cdot \mathrm{OH}^{+}$would readily tautomerise to a mixture of cis- and trans-hyponitrous acids, where cis-hyponitrous acids would decompose rapidly to $\mathrm{N}_{2} \mathrm{O}$ and water, leaving a small amount of the stable trans-form ${ }^{37-39}$.

The rate equation has been reported as $\mathrm{r}_{\mathrm{N} 2 \mathrm{O}}=k \cdot\left[\mathrm{NO}_{2}^{-}\right] \cdot\left[\mathrm{NH}_{2} \mathrm{OH}\right]$ or $k \cdot\left[\mathrm{HNO}_{2}\right] \cdot\left[\mathrm{NH}_{2} \mathrm{OH}\right]$ or $k \cdot\left[\mathrm{H}^{+}\right] \cdot\left[\mathrm{HNO}_{2}\right] \cdot\left[\mathrm{NH}_{2} \mathrm{OH}\right]^{21,27,37,39,40}$, and the rate constant has been shown to depend on $\mathrm{pH}^{37,40}$. For instance, Bennett et al. (1982) observed that $k$ values rose with increasing $\mathrm{H}^{+}$but decreased at 2 $\mathrm{M}(\mathrm{pH}=-0.3)^{40}$. The dependence of $k$ value on $\mathrm{pH}$ was suggested to be due to a change in the ratedetermining step from the nitrosation step that converts the $\mathrm{NO}^{+}$group to $\mathrm{ON} \cdot \mathrm{NH}_{2} \cdot \mathrm{OH}^{+}{ }^{40}$. Alternatively, it could be understood in terms of the effect of $\mathrm{pH}$ on the decomposition or rearrangement of $\mathrm{ON} \cdot \mathrm{NH}_{2} \cdot \mathrm{OH}^{+} 37,38$. Our observation of decreasing $k$ values at more alkaline $\mathrm{pH}$ agrees with Bennett et al. (1982) as the $\mathrm{pH}$ range tested (4-9) was far above -0.3 (Figure 3) ${ }^{40}$.

To obtain the best description of the experimental data, different rate equations were compared (SI Table S3). The commonly applied equation $-\mathrm{r}_{\mathrm{N} 2 \mathrm{O}}=k \cdot\left[\mathrm{NO}_{2}^{-}\right] \cdot\left[\mathrm{NH}_{2} \mathrm{OH}\right]$ - presented the largest error with NRMSE 8-34 times higher than the other four rate equations, while expressing $k$ as a function of $\mathrm{pH}$ and considering $\mathrm{HNO}_{2}$ as reactant provides the best experimental data fit.

\section{Comparison of reported abiotic and biotic $\mathrm{N}_{2} \mathrm{O}$ production}

Most studies that have examined abiotic $\mathrm{N}_{2} \mathrm{O}$ production did not monitor $\mathrm{NH}_{2} \mathrm{OH}$ concentrations and consider the nitrogen mass balance (SI Table $\mathrm{S} 4$ ). The variable $\mathrm{N}_{2} \mathrm{O}$ yield relative to the amount 
of $\mathrm{NH}_{2} \mathrm{OH}$ oxidized observed in this study (e.g. $24-192 \%$ for $\mathrm{NH}_{2} \mathrm{OH}$ oxidation by $\mathrm{HNO}_{2}$ ) clearly indicated the presence of side reactions (Figure 3-C).

The effect of $\mathrm{pH}$ on abiotic $\mathrm{N}_{2} \mathrm{O}$ production was examined by Soler-Jofra et al. (2016) and Kampschreur et al. (2011) ${ }^{18,24}$. Soler-Jofra et al. (2016) observed that $\mathrm{NH}_{2} \mathrm{OH}$ depletion rates during reaction with $\mathrm{HNO}_{2}$ increased at lower $\mathrm{pH}$ (4.3-7.6), yet $\mathrm{N}_{2} \mathrm{O}$ production rates were not monitored during the tests ${ }^{18}$. Here, we comprehensively quantified the effect of $\mathrm{pH}$ on $\mathrm{N}_{2} \mathrm{O}$ production rates and kinetics of the oxidation of $\mathrm{NH}_{2} \mathrm{OH}$ by $\mathrm{HNO}_{2}$ by continuously following changes of nitrogen species. In contrast to Kampschreur et al. (2011) ${ }^{24}$ who did not find a clear correlation between $\mathrm{pH}$ and $\mathrm{N}_{2} \mathrm{O}$ production, we observed that $\mathrm{N}_{2} \mathrm{O}$ production from the reduction of $\mathrm{HNO}_{2}$ by $\mathrm{Fe}^{2+}$ was significantly stimulated at acidic $\mathrm{pH}$.

In a separate study we quantified $\mathrm{N}_{2} \mathrm{O}$ emissions from a nitritation reactor from $\mathrm{pH} 6.5$ to 8.5 and observed that the specific net $\mathrm{N}_{2} \mathrm{O}$ production rates and the fractional $\mathrm{N}_{2} \mathrm{O}$ yield increased sevenfold from $\mathrm{pH}=6.5$ to 8 , and decreased slightly with further $\mathrm{pH}$ increase to $8.5(\mathrm{p}<0.05){ }^{42}$. The results were consistent with previous studies: Law et al. (2011) showed that the specific $\mathrm{N}_{2} \mathrm{O}$ production rate increased with $\mathrm{pH}$ to the maximum at $\mathrm{pH}=8$ in the investigated $\mathrm{pH}$ range of $6.0-8.5$ ${ }^{43}$, while Rathnayake et al. (2015) reported highest $\mathrm{N}_{2} \mathrm{O}$ emission at $\mathrm{pH}=7.5$ in a $\mathrm{PN}$ reactor $(\mathrm{pH}=$ 6.5-8.5 ${ }^{44}$. Abiotic $\mathrm{r}_{2} 2 \mathrm{O}$ in the reactor was estimated from $\mathrm{NH}_{2} \mathrm{OH}$ oxidation by $\mathrm{HNO}_{2}$ because its rN2O was 1-3 orders of magnitude higher compared to other abiotic reactions. Further investigations are required to completely quantify the reaction kinetics of $\mathrm{NH}_{2} \mathrm{OH}$ oxidation by $\mathrm{Fe}^{3+}$, and $\mathrm{HNO}_{2}^{-}$ reduction by $\mathrm{Fe}^{2+}$, and the corresponding contributions to $\mathrm{N}_{2} \mathrm{O}$ in nitritation systems. Based on the estimated reaction rate constants (Figure 1, 3, SI Table S4) and the measured $\mathrm{NH}_{2} \mathrm{OH}$ and $\mathrm{HNO}_{2}$ concentrations during reactor operation, abiotic $\mathrm{N}_{2} \mathrm{O}$ production rates were estimated at different $\mathrm{pH}$ considering the oxidation of $\mathrm{NH}_{2} \mathrm{OH}$ by $\mathrm{HNO}_{2}$ and $\mathrm{NH}_{2} \mathrm{OH}$ disproportionation plus oxidation by $\mathrm{O}_{2}$ (Table 1). The estimated abiotic rN2O values were 1-5 orders of magnitude lower than the total $\mathrm{r}_{\mathrm{N} 2 \mathrm{O}}$ 
value measured in the reactor across the examined $\mathrm{pH}$ range. The abiotic contributions accounted for less than $3 \%$ of total $\mathrm{N}_{2} \mathrm{O}$ production and varied with $\mathrm{pH}$, increasing from $0.025 \%$ at $\mathrm{pH}=8$ to

$3112.6 \%$ at $\mathrm{pH}=6.5$. Abiotic contributions below $3 \%$ of total $\mathrm{N}_{2} \mathrm{O}$ production here are consistent with

312 reported proportions of $\mathrm{NH}_{4}^{+}$converted to $\mathrm{N}_{2} \mathrm{O}(\leq 0.12 \%)$ via extracellular abiotic $\mathrm{NH}_{2} \mathrm{OH}$

313 conversion in pure AOB cultures ${ }^{26}$. In contrast, in other studies ${ }^{17-19,27}$, both abiotic and biotic

314 routes were suggested to contribute in a comparable degree to $\mathrm{N}_{2} \mathrm{O}$ emissions $($ at $\mathrm{pH}=7)($ Table 1$)$.

315 For example, Soler-Jofra et al. (2016) concluded that abiotic $\mathrm{r}_{\mathrm{N} 2 \mathrm{O}}(0.006 \mathrm{mM} / \mathrm{h})($ measured without

316 biomass) was of the same order of magnitude as total $\mathrm{r}_{\mathrm{N} 2 \mathrm{O}}(0.017 \mathrm{mM} / \mathrm{h})$ in a nitritation reactor ${ }^{18}$,

317 while Terada et al. (2017) and Harper et al. (2015) indicated abiotic hybrid $\mathrm{N}_{2} \mathrm{O}$ production as a

318 dominant pathway in a PN reactor, accounting for approximately $51 \%$ of the total $\mathrm{N}_{2} \mathrm{O}$ production

319 19,27. However, Soler-Jofra et al. (2016) performed off-line abiotic tests with initial $\mathrm{NH}_{2} \mathrm{OH}$ 320 concentration of $0.02 \mathrm{mM}$ and initial $\mathrm{HNO}_{2}$ concentration of $0.012 \mathrm{mM}$ to estimate an $\mathrm{r} 2 \mathrm{O}$ of 0.006

$321 \mathrm{mM} / \mathrm{h}$ and did not determine $k$ values. This initial $\mathrm{r}_{\mathrm{N} 2 \mathrm{O}}$ was used to estimate the abiotic $\mathrm{r}_{\mathrm{N} 2 \mathrm{O}}$ in a

322 nitritation reactor despite of a lower $\mathrm{NH}_{2} \mathrm{OH}$ in the reactor $(0.0043 \mathrm{mM}$ vs $0.02 \mathrm{mM}){ }^{18}$. The only $k$ 323 value $(0.049 \mathrm{~L} / \mathrm{mmol} / \mathrm{h})$ reported in Harper et al. (2015) was expressed with $\mathrm{NO}_{2}^{-}$as reactant ${ }^{27}$, 324 which we suggest as incorrect. Based on the estimated $k$ values in this study and the reported 325 experimental conditions, the reported abiotic $\mathrm{r}_{\mathrm{N} 2 \mathrm{O}}{ }^{18,19,27}$ were recalculated and estimated to be $1-2$ 326 orders of magnitude lower than those originally reported (Table 1). Hence, we contend that the 327 significance of abiotic $\mathrm{N}_{2} \mathrm{O}$ production has been overestimated in previous studies.

\section{Practical implications for nitrogen removal systems}

329 The highest $\mathrm{N}_{2} \mathrm{O}$ production rates were measured for $\mathrm{NH}_{2} \mathrm{OH}$ oxidation by $\mathrm{HNO}_{2}$, followed by $330 \mathrm{HNO}_{2}$ reduction by $\mathrm{Fe}^{2+}, \mathrm{NH}_{2} \mathrm{OH}$ oxidation by $\mathrm{Fe}^{3+}$, and finally $\mathrm{NH}_{2} \mathrm{OH}$ disproportionation and/or 331 oxidation by $\mathrm{O}_{2}$. Typical $\mathrm{NH}_{2} \mathrm{OH}$ concentrations measured in nitritation reactors vary from 0.002 $3320.007 \mathrm{mM}^{18,45}$. Compared to low $\mathrm{NO}_{2}^{-}$concentrations $(\leq 0.07 \mathrm{mM})$ in reactors treating typical 
domestic wastewaters ${ }^{46}, \mathrm{NO}_{2}^{-}$can reach up to $50 \mathrm{mM}$ in nitritation reactors treating high strength wastewaters ${ }^{47}$. Hence, abiotic $\mathrm{r}_{\mathrm{N} 2 \mathrm{O}}$ in nitritation (side-stream) reactors could be 1-3 orders of magnitude higher than in typical (main-stream) treatment reactors (SI Figure S5). Avoiding accumulation of $\mathrm{NO}_{2}{ }^{-}$as well as $\mathrm{HNO}_{2}$ could reduce $\mathrm{N}_{2} \mathrm{O}$ production via chemical reactions; such is possible by operating reactors at low $\mathrm{NH}_{4}{ }^{+}$removal rates. In addition, iron mediated reduction of $\mathrm{HNO}_{2}$ and oxidation of $\mathrm{NH}_{2} \mathrm{OH}$ can also contribute quantitatively to abiotic $\mathrm{N}_{2} \mathrm{O}$ production in nitritation systems. Hence minimizing iron dosage in earlier stages of WWTPs can prevent $\mathrm{N}_{2} \mathrm{O}$ emissions from chemical iron oxidation or reduction.

By applying the estimated abiotic reaction kinetic coefficients, abiotic $\mathrm{r}_{\mathrm{N} 2 \mathrm{O}}$ in other nitritation systems $(\mathrm{pH}=7-8)$ was estimated to be 1-3 orders of magnitude lower than the reported total $\mathrm{r}_{\mathrm{N} 2 \mathrm{O}}$ (SI Table S5). The estimated abiotic contribution ranged from 0.07 to $2.31 \%$ of total $\mathrm{N}_{2} \mathrm{O}$ production, consistent with the observations in our nitritation reactor (SI Table S5). Furthermore, abiotic $\mathrm{N}_{2} \mathrm{O}$ production rates would decrease but biotic $\mathrm{N}_{2} \mathrm{O}$ production rates would be enhanced at increasing $\mathrm{pH}$ (6.5-8.0). In summary, $\mathrm{N}_{2} \mathrm{O}$ production in nitritation systems is dominated by biotic pathways but abiotic pathways become important under extremely acidic $\mathrm{pH}(\leq 5)$. Therefore, $\mathrm{N}_{2} \mathrm{O}$ emissions from nitritation reactors are minimized at circum-neutral $\mathrm{pH}$, considering the effect of $\mathrm{pH}$ on both abiotic and biotic $\mathrm{N}_{2} \mathrm{O}$ production pathways. In addition, the estimated reaction kinetics for biologically-driven abiotic $\mathrm{N}_{2} \mathrm{O}$ production from the reaction of $\mathrm{NH}_{2} \mathrm{OH}$ and $\mathrm{NO}_{2}^{-}$can easily be incorporated into already established $\mathrm{N}_{2} \mathrm{O}$ models to estimate abiotic contributions under other wastewater treatment applications ${ }^{48}$.

To the best of our knowledge, this is the first study that comprehensively quantifies $\mathrm{N}_{2} \mathrm{O}$ production by dominant biotic reactions under environmental conditions relevant to nitritation bioreactors, a representative modern day $\mathrm{BNR}$ technology. The contribution of chemical reactions to $\mathrm{N}_{2} \mathrm{O}$ emissions appears to have been overestimated in recent studies on nitritation systems. Correct 
quantification of abiotic reaction kinetics and careful consideration of $\mathrm{pH}$ effects are required to assess the role of abiotic $\mathrm{N}_{2} \mathrm{O}$ production in $\mathrm{BNR}$ systems.

359

360

361

362

363

364

365

366

\section{ASSOCIATED CONTENT}

\section{Supporting Information}

List of Figure S1-S6, Table S1-S5 and Section 1-2.

\section{AUTHOR INFORMATION}

\section{Corresponding Author}

*E-mail: bfsm@env.dtu.dk; Tel: +45 4525 1600; Fax: +45 45932850

\section{Notes}

The authors declare no competing financial interest.

\section{ACKNOWLEDGEMENTS}

The work has been funded in part by the China Scholarship Council, the Innovation Fund Denmark (IFD) (Project LaGas, File No. 0603-00523B) and The Danish Council for Independent Research Technology and Production Sciences (FTP) (Project N2Oman, File No. 1335-00100B).

\section{REFERENCES}

(1) IPCC. Climate Change 2013: The Physical Science Basis; Cambridge, United Kingdom and New York, NY, USA, 2013.

(2) Kampschreur, M. J.; Temmink, H.; Kleerebezem, R.; Jetten, M. S. M.; van Loosdrecht, M. C. M. Nitrous oxide emission during wastewater treatment. Water Res. 2009, 43 (17), 4093-4103.

(3) Siegrist, H.; Salzgeber, D.; Eugster, J.; Joss, A. Anammox brings WWTP closer to energy autarky due to increased biogas production and reduced aeration energy for N-removal. Water Sci. Technol. 2008, 57 (3), 383.

(4) Kartal, B.; Kuenen, J. G.; van Loosdrecht, M. C. M. Sewage Treatment with Anammox. Science. 2010, 328 (5979), 702-703.

(5) Gao, K.; Zhao, J.; Ge, G.; Ding, X.; Wang, S.; Li, X.; Yu, Y. Effect of ammonium concentration on N2O emission during autotrophic nitritation under oxygen-limited conditions. Environ. Eng. Sci. 2017, 34 (2), 96102. 
(6) Mampaey, K. E.; De Kreuk, M. K.; van Dongen, U. G. J. M.; van Loosdrecht, M. C. M.; Volcke, E. I. P. Identifying N2O formation and emissions from a full-scale partial nitritation reactor. Water Res. 2016, 88, 575585. based sequential partial nitritation and anammox at full scale with contrasting N2O emissions. Water Res. 2011, 45 (9), 2811-2821.

(12) Tallec, G.; Garnier, J.; Billen, G.; Gousailles, M. Nitrous oxide emissions from secondary activated sludge in

(9) Lv, Y.; Ju, K.; Wang, L.; Chen, X.; Miao, R.; Zhang, X. Effect of pH on nitrous oxide production and emissions from a partial nitritation reactor under oxygen-limited conditions. Process Biochem. 2016, 51 (6), 765-771.

(10) Peng, L.; Ni, B.-J.; Ye, L.; Yuan, Z. The combined effect of dissolved oxygen and nitrite on N2O production by ammonia oxidizing bacteria in an enriched nitrifying sludge. Water Res. 2015, 73 (2), 29-36.

Kampschreur, M. J.; Tan, N. C. G.; Kleerebezem, R.; Picioreanu, C.; Jetten, M. S. M.; Van Loosdrecht, M. C. M. Effect of dynamic process conditions on nitrogen oxides emission from a nitrifying culture. Environ. Sci. Technol. 2008, 42 (2), 429-435. nitrifying conditions of urban wastewater treatment plants: Effect of oxygenation level. Water Res. 2006, 40 (15), 2972-2980.

(13) Law, Y.; Ye, L.; Pan, Y.; Yuan, Z. Nitrous oxide emissions from wastewater treatment processes. Philos. Trans. R. Soc. B Biol. Sci. 2012, 367 (1593), 1265-1277.

(14) Wrage-Mönnig, N.; Horn, M. A.; Well, R.; Müller, C.; Velthof, G.; Oenema, O. The role of nitrifier denitrification in the production of nitrous oxide revisited. Soil Biol. Biochem. 2018, 123, A3-A16.

(15) Heil, J.; Vereecken, H.; Brüggemann, N. A review of chemical reactions of nitrification intermediates and their role in nitrogen cycling and nitrogen trace gas formation in soil. Eur. J. Soil Sci. 2016, 67 (1), 23-39.

(16) Zhu-Barker, X.; Cavazos, A. R.; Ostrom, N. E.; Horwath, W. R.; Glass, J. B. The importance of abiotic reactions for nitrous oxide production. Biogeochemistry 2015, 126 (3), 251-267.

(17) Soler-Jofra, A.; Picioreanu, C.; Yu, R.; Chandran, K.; van Loosdrecht, M. C. M.; Pérez, J. Importance of hydroxylamine in abiotic $\mathrm{N} 2 \mathrm{O}$ production during transient anoxia in planktonic axenic Nitrosomonas cultures. Chem. Eng. J. 2018, 335, 756-762.

(18) Soler-Jofra, A.; Stevens, B.; Hoekstra, M.; Picioreanu, C.; Sorokin, D.; van Loosdrecht, M. C. M.; Pérez, J. Importance of abiotic hydroxylamine conversion on nitrous oxide emissions during nitritation of reject water. Chem. Eng. J. 2016, 287, 720-726.

(19) Terada, A.; Sugawara, S.; Hojo, K.; Takeuchi, Y.; Riya, S.; Harper, W. F.; Yamamoto, T.; Kuroiwa, M.; Isobe, K.; Katsuyama, C.; Suwa, Y.; Koba, K; Hosomi, M. Hybrid Nitrous Oxide Production from a Partial Nitrifying Bioreactor: Hydroxylamine Interactions with Nitrite. Environ. Sci. Technol. 2017, 51 (5), 2748-2756.

(20) Schreiber, F.; Wunderlin, P.; Udert, K. M.; Wells, G. F. Nitric oxide and nitrous oxide turnover in natural and engineered microbial communities: Biological pathways, chemical reactions, and novel technologies. Front.

Microbiol. 2012, 3, 372. 
(21) Döring, C.; Gehlen, H. Über die Kinetik der Reaktion zwischen Hydroxylamin und Salpetriger Säure. J. Inorg. Gen. Chem. 1961, 312 (1-2), 32-44.

(22) Moews, P. C.; Audrieth, L. F. The autoxidation of hydroxylamine. J. Inorg. Nucl. Chem. 1959, 11 (3), 242-246.

(23) Bonner, F. T.; Hughes, M. N. The Aqueous Solution Chemistry of Nitrogen in Low Positive Oxidation States. Comments Inorg. Chem. 1988, 7 (4), 215-234.

(24) Kampschreur, M. J.; Kleerebezem, R.; de Vet, W. W. J. M.; van Loosdrecht, M. C. M. Reduced iron induced nitric oxide and nitrous oxide emission. Water Res. 2011, 45 (18), 5945-5952.

(25) Butler, J. H.; Gordon, L. I. Rates of Nitrous Oxide Production in the Oxidation of Hydroxylamine by Iron(III). Inorg. Chem 1986, 25, 4573-4577.

(26) Liu, S.; Han, P.; Hink, L.; Prosser, J. I.; Wagner, M.; Brüggemann, N. Abiotic Conversion of Extracellular NH $2 \mathrm{OH}$ Contributes to $\mathrm{N} 2 \mathrm{O}$ Emission during Ammonia Oxidation. Environ. Sci. Technol. 2017, 51 (22), 1312213132.

(27) Harper, W. F.; Takeuchi, Y.; Riya, S.; Hosomi, M.; Terada, A. Novel abiotic reactions increase nitrous oxide production during partial nitrification: Modeling and experiments. Chem. Eng. J. 2015, 281, 1017-1023.

(28) van de Graaf, A. A.; Bruijn, P. de; Robertson, L. A.; Jetten, M. S. M.; Kuenen, J. G. Autotrophic growth of anaerobic ammonium-oxidizing micro-organisms in a fluidized bed reactor. Microbiology 1996, 142 (8), 21872196.

(29) Su, Q.; Ma, C.; Domingo-Félez, C.; Kiil, A. S.; Thamdrup, B.; Jensen, M. M.; Smets, B. F. Low nitrous oxide production through nitrifier-denitrification in intermittent-feed high-rate nitritation reactors. Water Res. 2017, 123, 429-438.

(30) Frear, D. S.; Burrell, R. C. Spectrophotometric Method for Determining Hydroxylamine Reductase Activity in Higher Plants. Anal. Chem. 1955, 27 (10), 1664-1665.

(31) Viollier, E.; Inglett, P. .; Hunter, K.; Roychoudhury, A. .; Van Cappellen, P. The ferrozine method revisited: $\mathrm{Fe}(\mathrm{II}) / \mathrm{Fe}(\mathrm{III})$ determination in natural waters. Appl. Geochemistry 2000, 15 (6), 785-790.

(32) Weiss, R. F.; Price, B. A. Nitrous oxide solubility in water and seawater. Mar. Chem. 1980, 8 (4), 347-359.

(33) Bremner, J. M.; Blackmer, A. M.; Waring, S. A. Formation of nitrous oxide and dinitrogen by chemical decomposition of hydroxylamine in soils. Soil Biol. Biochem. 1980, 12 (3), 263-269.

(34) Alluisetti, G. E.; Almaraz, A. E.; Amorebieta, V. T.; Doctorovich, F.; Olabe, J. A. Metal-Catalyzed Anaerobic Disproportionation of Hydroxylamine. Role of diazene and nitroxyl intermediates in the formation of N2, N2O, NO+, and NH3. J. Am. Chem. Soc. 2004, 126 (41), 13432-13442.

(35) Anderson, J. H. The copper-catalysed oxidation of hydroxylamine. Analyst 1964, 89 (1058), 357.

(36) Huang, Y. H.; Zhang, T. C. Nitrite reduction and formation of corrosion coatings in zerovalent iron systems. Chemosphere 2006, 64 (6), 937-943.

(37) Hughes, M. N.; Stedman, G. Kinetics and mechanism of the reaction between nitrous acid and hydroxylamine. Part I. J. Chem. Soc. 1963, 2824.

(38) Hussain, M. A.; Stedman, G.; Hughes, M. N. Kinetics and mechanism of the reaction between nitrous acid and hydroxylamine. Part III. The formation of hyponitrous acid. J. Chem. Soc. B Phys. Org. 1968, 597.

(39) Bothner-By, A.; Friedman, L. The Reaction of Nitrous Acid with Hydroxylamine. J. Chem. Phys. 1952, 20 (3), $459-462$. 
(40) Bennett, M. R.; Maya, L.; Brown, G. M.; Posey, F. A. Oxidation of hydroxylamine by nitrous and nitric acids. Inorg. Chem. 1982, 21 (6), 2461-2468.

(41) Morgan, T. D. B.; Stedman, G.; Hughes, M. N. Kinetics and mechanism of the reaction between nitrous acid and hydroxylamine. Part II. The alkyl hydroxylamines. J. Chem. Soc. B Phys. Org. 1968, 0 (0), 344.

(42) Su, Q.; Domingo-Félez, C.; Zhang, Z.; Blum, J.-M.; Jensen, M. M.; Smets, B. F. The effect of pH on N2O production through nitrifier-denitrification in intermittently-fed nitritation reactors (under review). 2019.

(43) Law, Y.; Lant, P.; Yuan, Z. The effect of $\mathrm{pH}$ on $\mathrm{N} 2 \mathrm{O}$ production under aerobic conditions in a partial nitritation system. Water Res. 2011, 45 (18), 5934-5944.

(44) Rathnayake, R. M. L. D.; Oshiki, M.; Ishii, S.; Segawa, T.; Satoh, H.; Okabe, S. Effects of dissolved oxygen and $\mathrm{pH}$ on nitrous oxide production rates in autotrophic partial nitrification granules. Bioresour. Technol. 2015,

(45) Kinh, C. T.; Ahn, J.; Suenaga, T.; Sittivorakulpong, N.; Noophan, P.; Hori, T.; Riya, S.; Hosomi, M.; Terada, A. Free nitrous acid and $\mathrm{pH}$ determine the predominant ammonia-oxidizing bacteria and amount of $\mathrm{N} 2 \mathrm{O}$ in a partial nitrifying reactor. Appl. Microbiol. Biotechnol. 2017, 101 (4), 1673-1683.

(46) Ni, B.; Ye, L.; Law, Y.; Byers, C.; Yuan, Z. Mathematical Modeling of Nitrous Oxide (N2O) Emissions from Full-Scale Wastewater Treatment Plants. Environ. Sci. Technol. 2013, 47 (14), 7795-7803.

(47) van Dongen, U.; Jetten, M. S.; van Loosdrecht, M. C. The SHARON-Anammox process for treatment of ammonium rich wastewater. Water Sci. Technol. 2001, 44 (1), 153-160.

482 


\section{FIGURE AND TABLE CAPTION}

Figure 1. $\mathrm{NH}_{2} \mathrm{OH}$ disproportionation and/or oxidation by $\mathrm{O}_{2}$ at different $\mathrm{pH}$ set-points (Scenario 1).
(A) Averaged $\mathrm{N}_{2} \mathrm{O}$ production rate (bar) and rate constant ( $k$ ) (scatter); (B) Averaged $\mathrm{NH}_{2} \mathrm{OH}$ depletion rate; (C) $\mathrm{N}_{2} \mathrm{O}$ yield relative to the amount of $\mathrm{NH}_{2} \mathrm{OH}$ oxidized (\%). $k$ and $\mathrm{N}_{2} \mathrm{O}$ yield relative to the amount of $\mathrm{NH}_{2} \mathrm{OH}$ oxidized were calculated based on the reaction kinetics and stoichiometry of $\mathrm{NH}_{2} \mathrm{OH}$ disproportionation (Eq. 12 and 9, respectively). Gray dot bars represent the tests that were not performed. Error bars indicate standard deviations of measurements.

Figure 2. Chemical dynamics during $\mathrm{NH}_{2} \mathrm{OH}$ oxidation by $\mathrm{HNO}_{2}$ in $\mathrm{Scenario}_{1}$ (A) and Scenario 2 (B). (A) and (B) were conducted in synthetic medium under low DO condition $(<1 \mathrm{mg} \mathrm{O} / \mathrm{L})$.

Figure 3. $\mathrm{NH}_{2} \mathrm{OH}$ oxidation by $\mathrm{HNO}_{2}$ at different $\mathrm{pH}$ set-points (Scenario.1). (A) Averaged $\mathrm{N}_{2} \mathrm{O}$ production rate (bar) and rate constant (k) (scatter); (B) Averaged $\mathrm{NH}_{2} \mathrm{OH}$ depletion rate; (C) $\mathrm{N}_{2} \mathrm{O}$ yield relative to the amount of $\mathrm{NH}_{2} \mathrm{OH}$ oxidized (\%). Gray dot bars represent the tests that weren't performed. Error bars indicate standard deviations of measurements.

Table 1. The contribution of abiotic reactions to overall $\mathrm{N}_{2} \mathrm{O}$ production in nitritation reactors. 


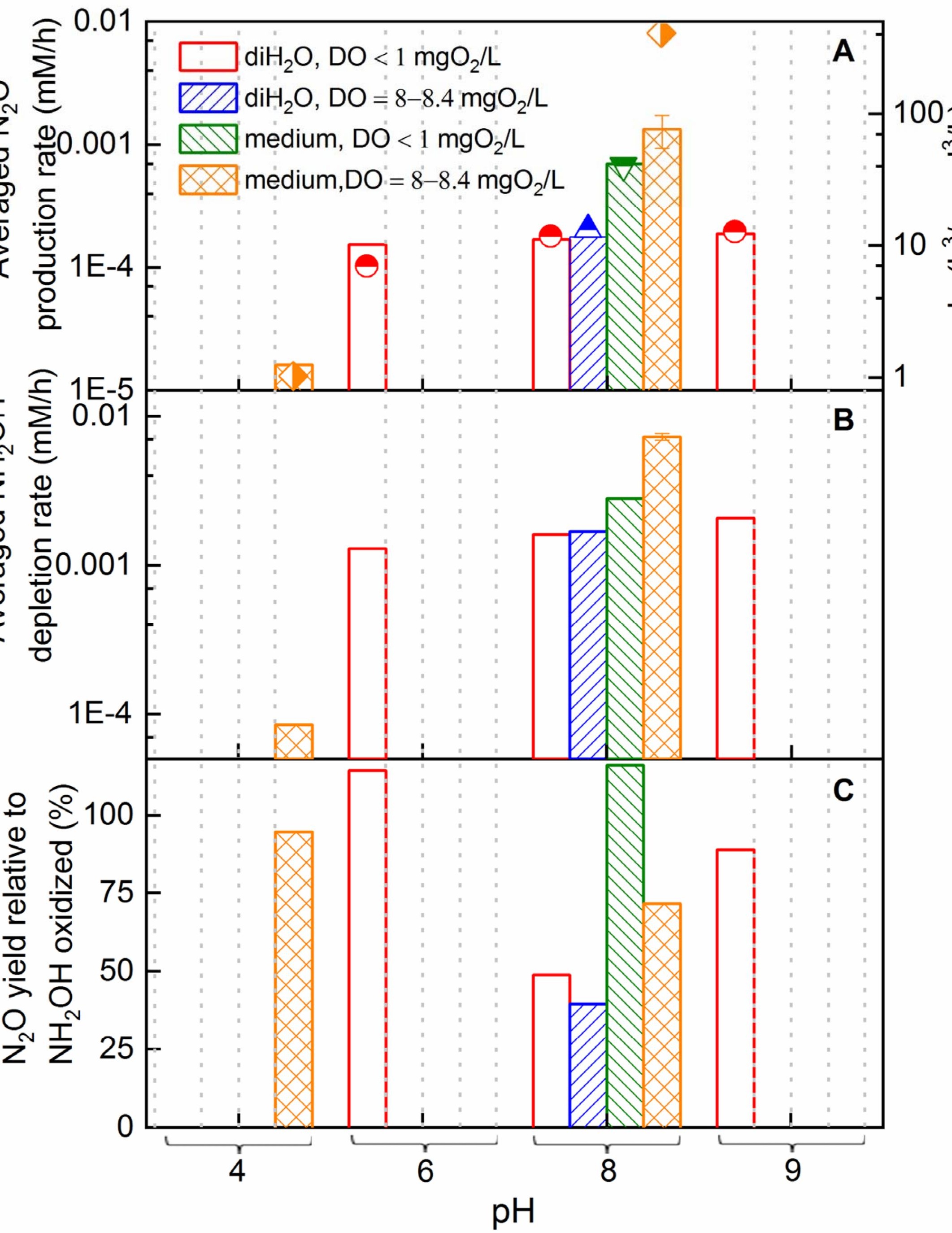




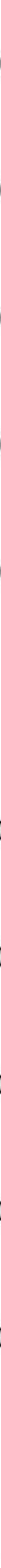




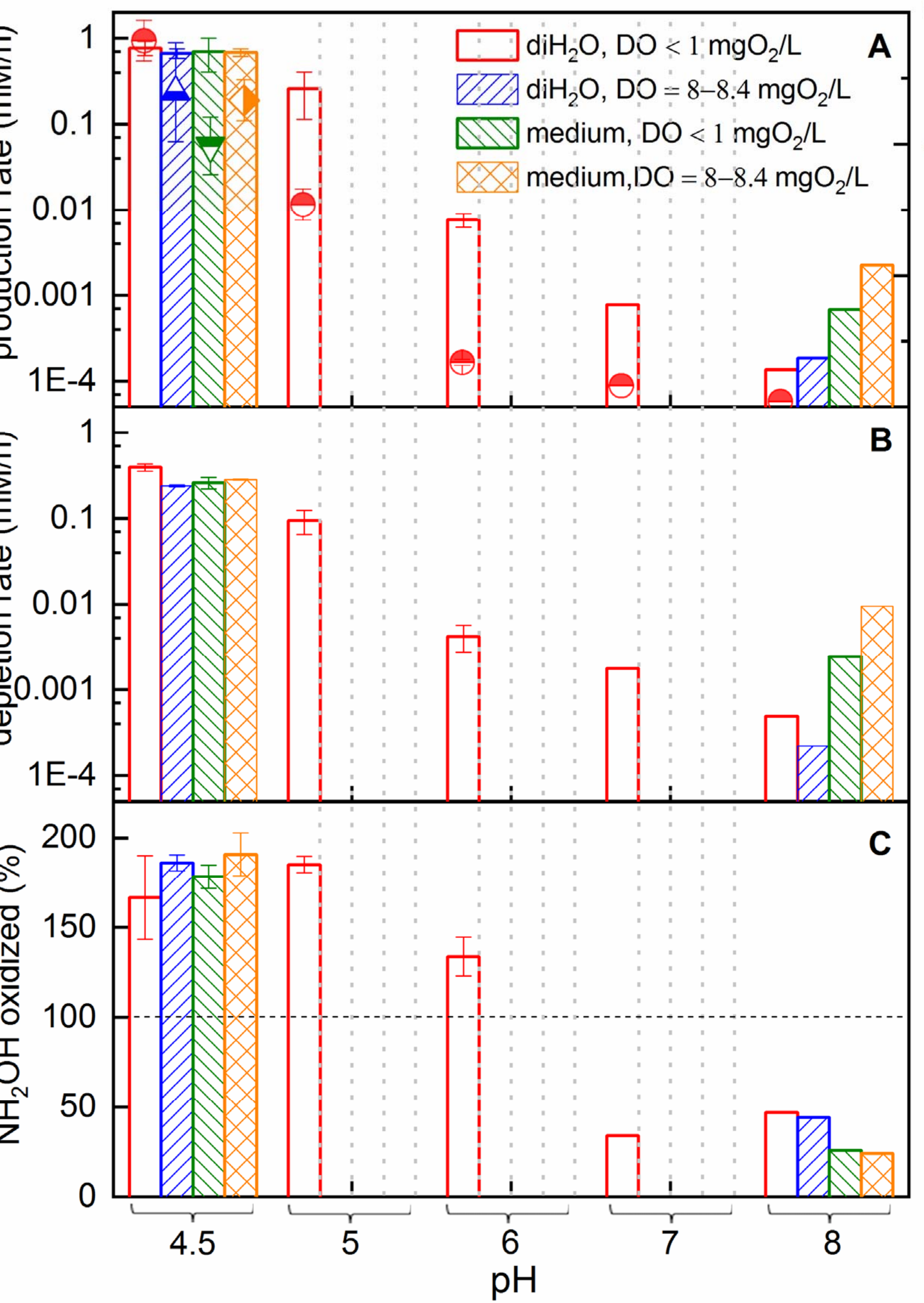


Table 1. The contribution of abiotic reactions to overall $\mathrm{N}_{2} \mathrm{O}$ production in nitritation reactors.

\begin{tabular}{|c|c|c|c|c|c|c|c|c|c|c|c|c|}
\hline \multirow{3}{*}{ Reference } & \multicolumn{6}{|c|}{ Total $\mathrm{N}_{2} \mathrm{O}$ production in nitritation reactors } & \multicolumn{6}{|c|}{ Abiotic $\mathrm{N}_{2} \mathrm{O}$ production } \\
\hline & \multicolumn{5}{|c|}{ Experimental condition } & \multirow{2}{*}{$\begin{array}{l}\text { Measured } \\
\text { total } \mathrm{N}_{2} \mathrm{O} \\
\text { production } \\
\text { rates } \\
(\mathrm{mM} / \mathrm{h})\end{array}$} & \multirow{2}{*}{ Considered pathway } & \multirow{2}{*}{ Method $^{c}$} & \multicolumn{2}{|c|}{$\begin{array}{c}\text { Estimated abiotic } \mathrm{N}_{2} \mathrm{O} \\
\text { production rates }(\mathrm{mM} / \mathrm{h})^{\mathrm{e}}\end{array}$} & \multicolumn{2}{|c|}{$\begin{array}{c}\text { Fraction of abiotic } \\
\text { pathway to total } \mathrm{N}_{2} \mathrm{O} \\
\text { production }(\%)\end{array}$} \\
\hline & $\begin{array}{l}\text { Reactor } \\
\text { types }\end{array}$ & $\mathrm{pH}$ & $\begin{array}{l}\mathrm{NH}_{2} \mathrm{OH} \\
(\mathrm{mM})\end{array}$ & $\begin{array}{l}\mathrm{HNO}_{2} \\
(\mathrm{mM})\end{array}$ & $\begin{array}{l}\mathrm{NO}_{2}^{-} \\
(\mathrm{mM})\end{array}$ & & & & $\begin{array}{l}\text { Original } \\
\text { Estimation }\end{array}$ & $\begin{array}{l}\text { Estimation } \\
\text { based on } k \\
\text { in this study }\end{array}$ & $\begin{array}{c}\text { Original } \\
\text { Estimatio } \\
\mathrm{n}\end{array}$ & $\begin{array}{l}\text { Estimation } \\
\text { based on } k \text { in } \\
\text { this study }\end{array}$ \\
\hline \multirow{3}{*}{ This study } & \multirow{3}{*}{$\begin{array}{l}\text { Lab-scale, } \\
\text { nitritation, } \\
\text { SBR }\end{array}$} & $6.5^{\mathrm{a}}$ & $\begin{array}{c}4.5 \pm 0.58 \\
\times 10^{-3} \mathrm{a}\end{array}$ & $\begin{array}{l}4.6 \pm 0.87 \\
\times 10^{-3} \mathrm{a}\end{array}$ & $\underset{\mathrm{a}}{11.7 \pm 1.8}$ & $\begin{array}{l}5.6 \pm 2.3 \\
\times 10^{-3} \mathrm{a}\end{array}$ & $\begin{array}{c}\mathrm{NH}_{2} \mathrm{OH} \text { oxidation by } \\
\mathrm{HNO}_{2} \\
\mathrm{NH}_{2} \mathrm{OH} \\
\text { disproportionation } \\
\text { and/or oxidation by } \mathrm{O}_{2}\end{array}$ & \multirow{3}{*}{$\begin{array}{l}\text { Abiotic batch } \\
\text { tests without } \\
\text { biomass }\end{array}$} & \multicolumn{2}{|c|}{$\begin{array}{l}1.5 \pm 0.35 \\
\times 10^{-4}\end{array}$} & \multicolumn{2}{|c|}{$2.6 \pm 1.2$} \\
\hline & & $7.0^{\mathrm{a}}$ & $\begin{array}{c}4.1 \pm 1.2 \\
\times 10^{-3} \mathrm{a} \\
\end{array}$ & $\begin{array}{l}2.1 \pm 0.15 \\
\times 10^{-3} \mathrm{a} \\
\end{array}$ & $\begin{array}{c}16.6 \pm 0.8 \\
5^{\mathrm{a}} \\
\end{array}$ & $\begin{array}{l}2.0 \pm 1.0 \\
\times 10^{-2} \mathrm{a} \\
\end{array}$ & $\begin{array}{c}\mathrm{NH}_{2} \mathrm{OH} \text { oxidation by } \\
\mathrm{HNO}_{2}\end{array}$ & & \multicolumn{2}{|c|}{$\begin{array}{l}2.9 \pm 0.91 \\
\times 10^{-5}\end{array}$} & \multicolumn{2}{|c|}{$\begin{array}{c}1.5 \pm 0.87 \\
\times 10^{-1} \\
\end{array}$} \\
\hline & & $8.0^{\mathrm{a}}$ & $\begin{array}{l}3.7 \pm 1.0 \\
\times 10^{-3 a}\end{array}$ & $\begin{array}{l}2.7 \pm 0.080 \\
\times 10^{-4} \mathrm{a}\end{array}$ & $\begin{array}{c}20.2 \pm 0.1 \\
4^{\mathrm{a}}\end{array}$ & $\begin{array}{l}7.0 \pm 1.3 \\
\times 10^{-2} \mathrm{a}\end{array}$ & $\begin{array}{c}\mathrm{NH}_{2} \mathrm{OH} \text { oxidation by } \\
\mathrm{HNO}_{2} \\
\mathrm{NH}_{2} \mathrm{OH} \\
\text { disproportionation } \\
\text { and/or oxidation by } \mathrm{O}_{2}\end{array}$ & & \multicolumn{2}{|c|}{$1.8 \times 10^{-5}$} & \multicolumn{2}{|c|}{$\begin{array}{l}2.5 \pm 0.47 \\
\times 10^{-2}\end{array}$} \\
\hline $\begin{array}{l}\text { Terada et } \\
\text { al. (2017) }\end{array}$ & $\begin{array}{c}\text { Bath tests } \\
\text { with AOB } \\
\text { enriched } \\
\text { biomass } \\
\end{array}$ & 7 & $\begin{array}{l}7.1 \times 10^{-2}- \\
1.4^{b}\end{array}$ & $6.4 \times 10^{-3 \mathrm{~b}}$ & $28.6^{b}$ & $\underset{b}{2 \times 10^{-1}-3.3}$ & $\begin{array}{c}\mathrm{NH}_{2} \mathrm{OH} \text { oxidation by } \\
\mathrm{HNO}_{2}\end{array}$ & $\begin{array}{c}\text { Abiotic batch } \\
\text { tests with/without } \\
\text { biomass }\end{array}$ & $\begin{array}{l}5 \times 10^{-2}- \\
9 \times 10^{-1} \mathrm{~b}\end{array}$ & $\begin{array}{l}1.4 \times 10^{-3}- \\
2.8 \times 10^{-2} \mathrm{~b}\end{array}$ & 51 & $\begin{array}{l}6.9 \times 10^{-1}- \\
8.3 \times 10^{-1} \mathrm{~b}\end{array}$ \\
\hline $\begin{array}{l}\text { Soler- } \\
\text { Jofra et al. } \\
(2016)\end{array}$ & $\begin{array}{l}\text { Full-scale, } \\
\text { PN, } \\
\text { SHARON, } \\
\text { flocs } \\
\end{array}$ & 7 & $4.3 \times 10^{-3} \mathrm{~b}$ & $1.2 \times 10^{-2 \mathrm{~b}, \mathrm{~d}}$ & $46.4^{b}$ & $1.7 \times 10^{-2 b}$ & $\begin{array}{c}\mathrm{NH}_{2} \mathrm{OH} \text { oxidation by } \\
\mathrm{HNO}_{2}\end{array}$ & $\begin{array}{l}\text { Abiotic batch } \\
\text { tests without } \\
\text { biomass }\end{array}$ & $1.1 \times 10^{-3 \mathrm{~b}, \mathrm{e}}$ & $1.7 \times 10^{-4 b}$ & $6.8^{b}$ & $1^{\mathrm{b}}$ \\
\hline $\begin{array}{l}\text { Harper et } \\
\text { al. }(2015)\end{array}$ & $\begin{array}{l}\text { Bath tests } \\
\text { with AOB } \\
\text { enriched } \\
\text { biomass }\end{array}$ & 7 & $\begin{array}{c}7.1 \\
\times 10^{-3}- \\
1.4^{\mathrm{b}}\end{array}$ & $6.4 \times 10^{-3 \mathrm{~b}}$ & $28.6^{b}$ & $\begin{array}{l}1.5 \times 10^{-2}- \\
8.8 \times 10^{-1 b}\end{array}$ & $\begin{array}{c}\mathrm{NH}_{2} \mathrm{OH} \text { oxidation by } \\
\mathrm{HNO}_{2}\end{array}$ & $\begin{array}{c}\text { Abiotic batch } \\
\text { tests with/without } \\
\text { biomass and } \\
\text { combined with } \\
\text { model simulations }\end{array}$ & $\begin{array}{l}2 \times 10^{-2}- \\
7 \times 10^{-1}\end{array}$ & $\begin{aligned} & 1.4 \times 10^{-4} \\
- & 2.8 \times 10^{-2} b\end{aligned}$ & l & $\underset{b}{9.2 \times 10^{-1}}-3.2$ \\
\hline
\end{tabular}

${ }^{a}$ Numbers were retrieved from Su et al. (2018).

${ }^{\mathrm{b}}$ Numbers were calculated based on original data in literatures.

${ }^{\mathrm{c}}$ The details of experimental methods refer to materials and methods section and Table S1, S3 in Supporting Information.

${ }^{\mathrm{d}} \mathrm{HNO}_{2}$ was recalculated based on the Eq.6 in this study.

${ }^{\mathrm{e}}$ Estimated abiotic $\mathrm{N}_{2} \mathrm{O}$ production rate was calculated based on the equation of $\mathrm{r}_{\mathrm{N} 2 \mathrm{O}}=k \cdot\left[\mathrm{HNO}_{2}\right] \cdot\left[\mathrm{NH}_{2} \mathrm{OH}\right]$. 


\section{Supporting Information for:}

2 Abiotic nitrous oxide $\left(\mathbf{N}_{\mathbf{2}} \mathbf{O}\right)$ production is strongly $\mathbf{p H}$ dependent, but

\section{contributes little to overall $\mathrm{N}_{2} \mathrm{O}$ emissions in biological nitrogen}

Qingxian Su, Carlos Domingo-Félez, Marlene M. Jensen, Barth F. Smets ${ }^{*}$

Department of Environmental Engineering, Technical University of Denmark, 2800 Lyngby, Denmark

* Corresponding author. E-mail: bfsm@env.dtu.dk; Tel: +45 4525 1600; Fax: +45 45932850

\section{Contents:}

Number of pages: 17, number of figures: 6, number of tables: 5, number of sections: 2 .

Figure $\mathrm{S} 1$. Chemical dynamics during $\mathrm{NH}_{2} \mathrm{OH}$ disproportionation and/or oxidation by $\mathrm{O}_{2}$ in

Scenario 1

Figure S2. Chemical dynamics during the reduction of $\mathrm{HNO}_{2}$ by $\mathrm{Fe}^{2+}$ in Scenario 1 (A) and

Scenario 2 (B) 3

Figure S3. The reduction of $\mathrm{HNO}_{2}$ by $\mathrm{Fe}^{2+}$ at different $\mathrm{pH}$ values in Scenario 1............................ 4

Figure S4. Chemical dynamics during the oxidation of $\mathrm{NH}_{2} \mathrm{OH}$ by $\mathrm{Fe}^{3+}$ in Scenario 1................... 5

Figure S5. Predictions of abiotic $\mathrm{N}_{2} \mathrm{O}$ production rates $\left(\mathrm{r}_{\mathrm{N} 2 \mathrm{O}}\right)$ under operational conditions in reactors treating typical domestic wastewaters and nitritation reactors ............................................ 6

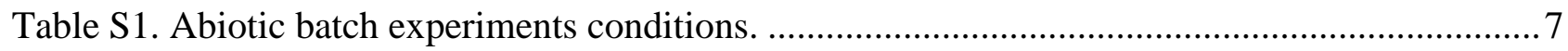

Table S2. The estimation procedure of $k$ values of abiotic reactions in Scenario1. ......................... 9

Table S3. Comparison of different rate equations to describe the oxidation of $\mathrm{NH}_{2} \mathrm{OH}$ by $\mathrm{HNO}_{2}$ in Scenario 1

Table S4. Summary of experimental conditions and calculated kinetic rates of abiotic reactions in

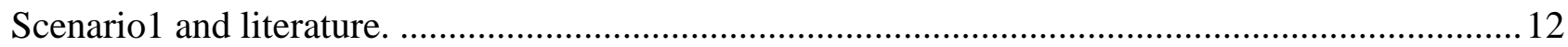

Table S5. Predictions of abiotic $\mathrm{N}_{2} \mathrm{O}$ production rates and the abiotic contributions to overall $\mathrm{N}_{2} \mathrm{O}$

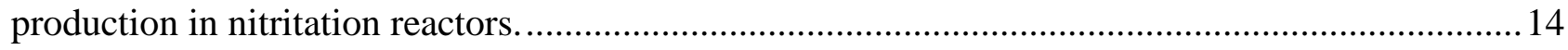

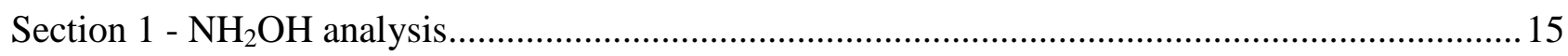

Section 2 - Measurement of the sensitivity and response time of sensors ..................................... 16

Figure S6. The sensitivity of $\mathrm{N}_{2} \mathrm{O}$ sensor towards $\mathrm{pH}$ changes. ................................................ 16

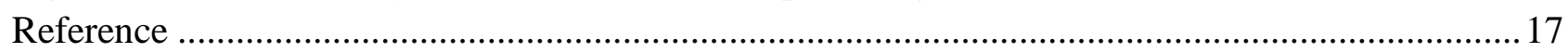




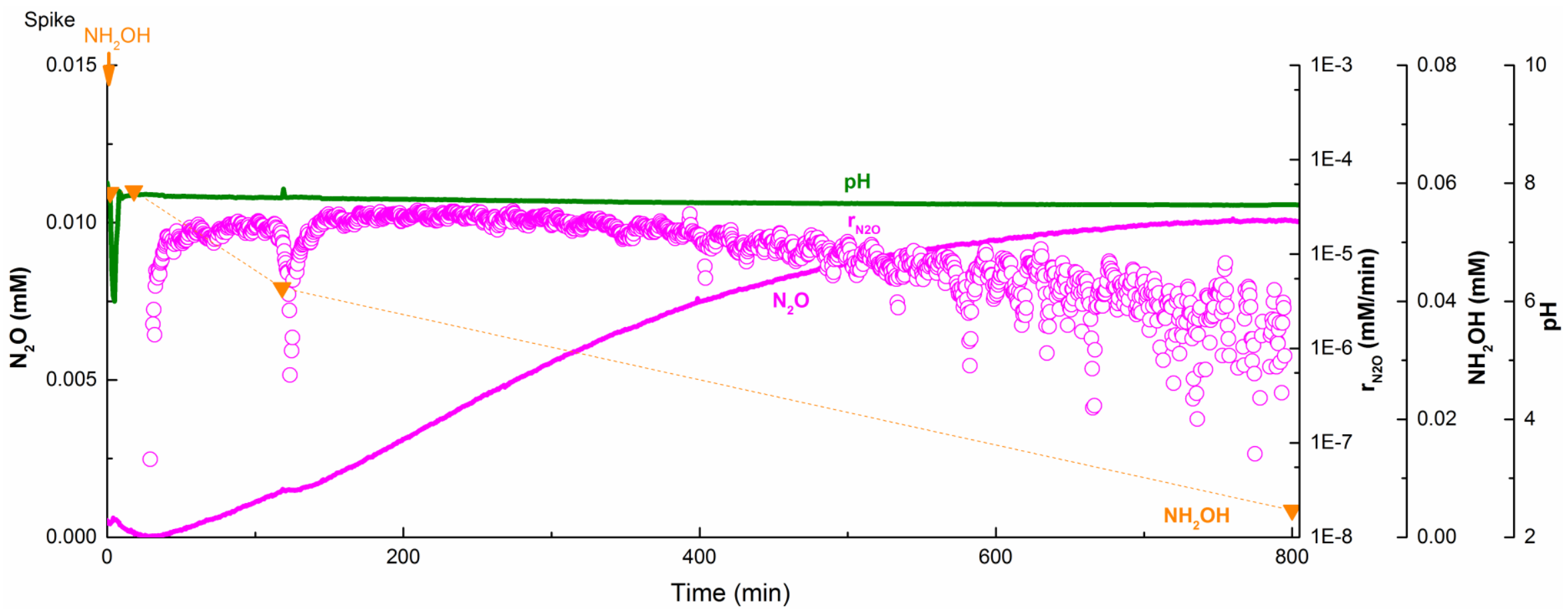



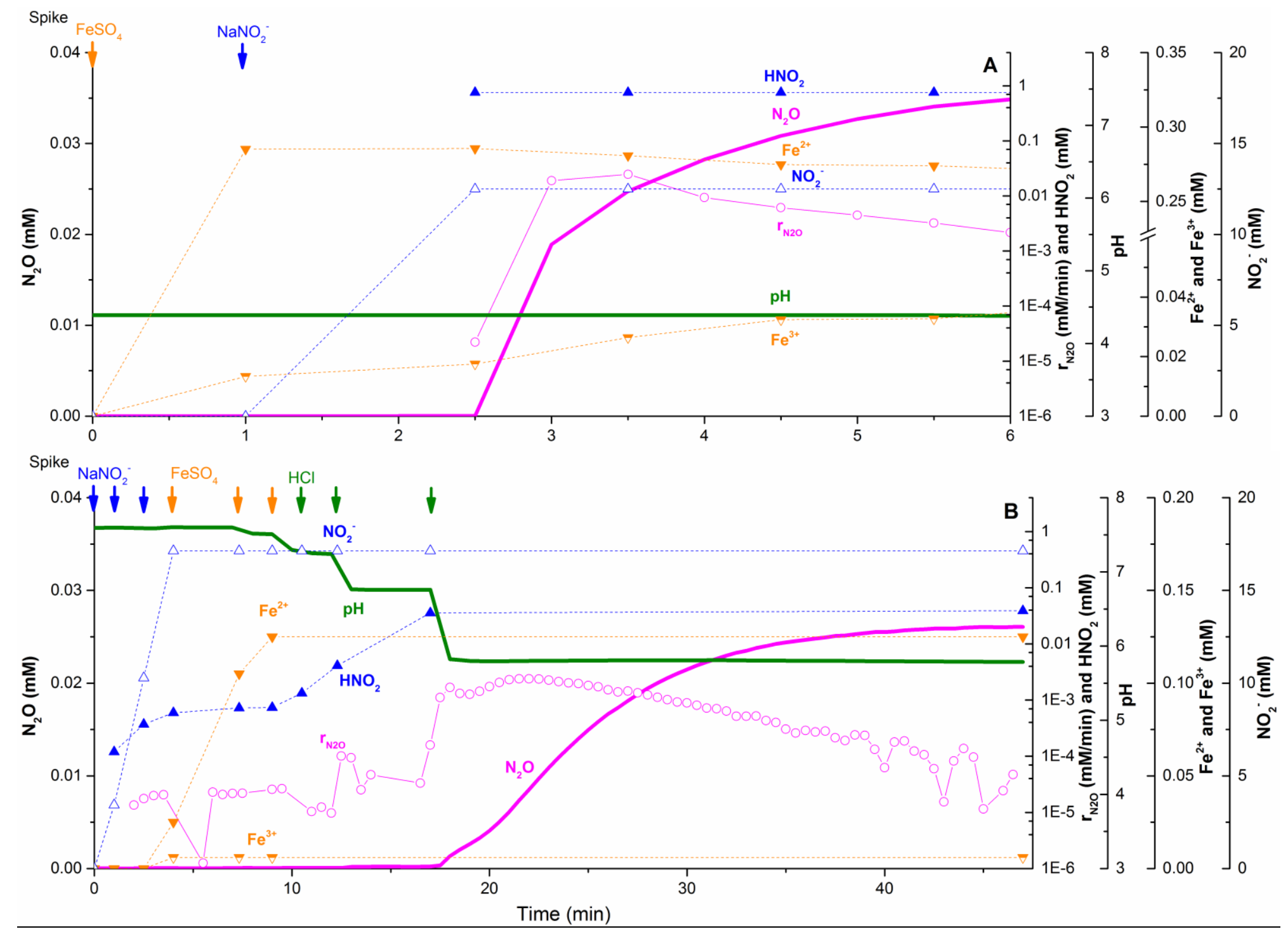

44 Figure S2. Chemical dynamics during the reduction of $\mathrm{HNO}_{2}$ by $\mathrm{Fe}^{2+}$ in Scenario 1 (A) and Scenario 2 (B). (A) was conducted in diH $\mathrm{H}_{2} \mathrm{O}$

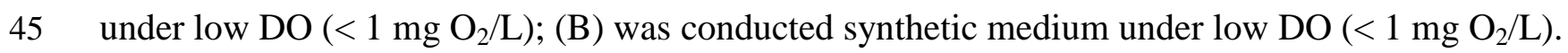




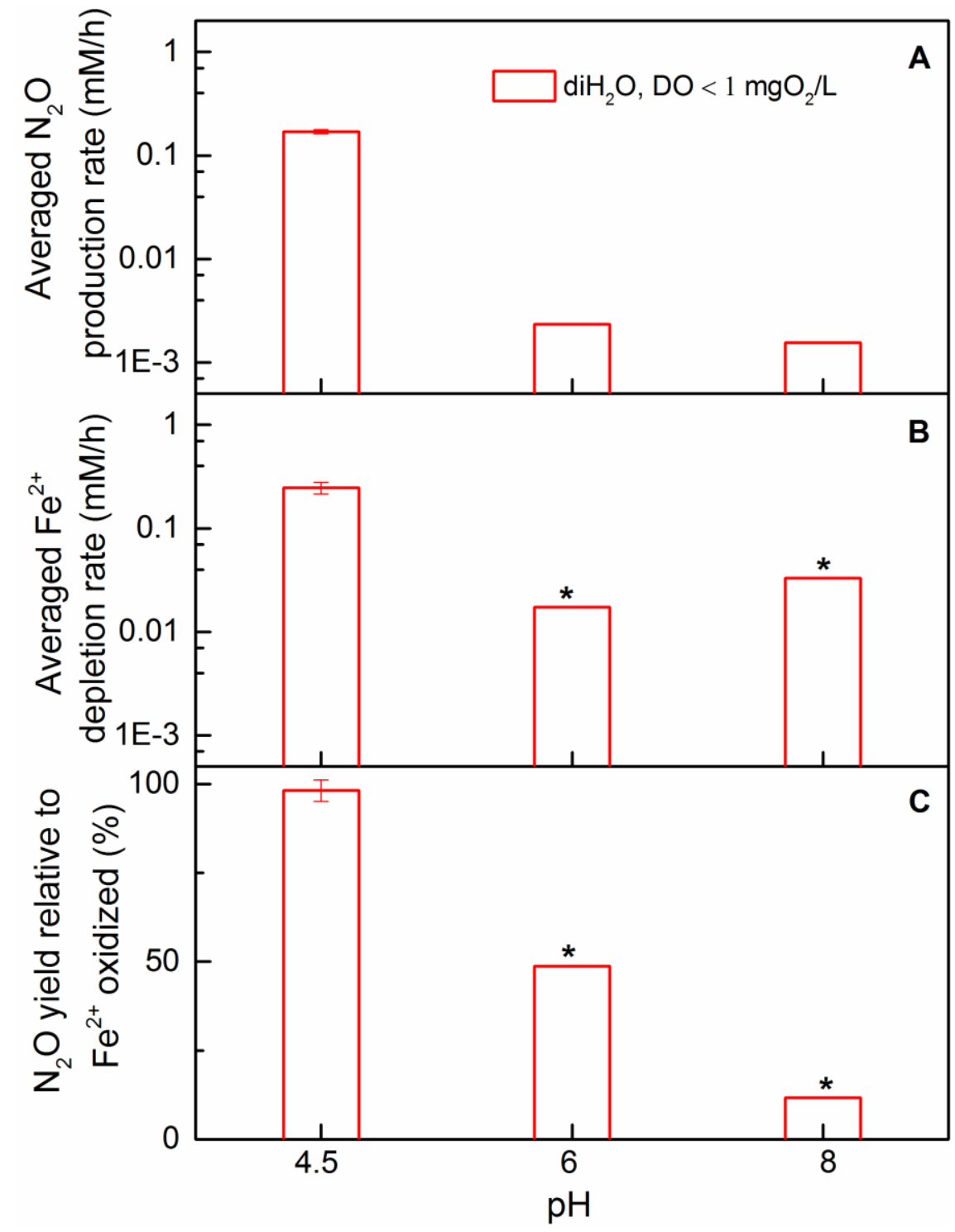

47 Figure $\mathrm{S} 3$. The reduction of $\mathrm{HNO}_{2}$ by $\mathrm{Fe}^{2+}$ at different $\mathrm{pH}$ values in Scenario 1. (A) Averaged $\mathrm{N}_{2} \mathrm{O}$

48 production rate (bar); (B) Averaged $\mathrm{Fe}^{2+}$ depletion rate; $(\mathrm{C}) \mathrm{N}_{2} \mathrm{O}$ yield relative to the amount of

$49 \mathrm{Fe}^{2+}$ oxidized (\%). Error bars indicate standard deviations of measurements.* indicates $\mathrm{Fe}^{2+}$

50 oxidation by $\mathrm{O}_{2}$ or $\mathrm{Fe}^{2+}$ oxidation coupling with $\mathrm{HNO}_{2}$ reduction to ammonium. 


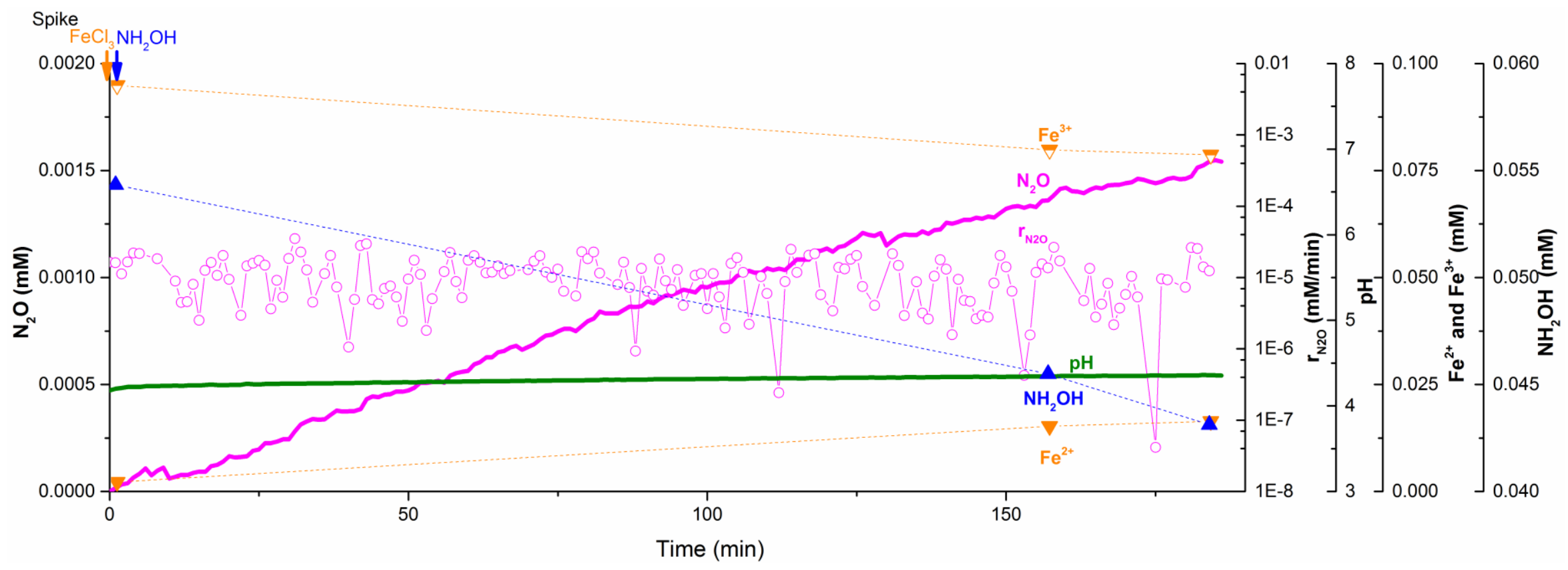

51

Figure S4. Chemical dynamics during the oxidation of $\mathrm{NH}_{2} \mathrm{OH}$ by $\mathrm{Fe}^{3+}$ in Scenario 1 . The test was conducted in diH $\mathrm{H}_{2} \mathrm{O}$ under low $\mathrm{DO}(<1$ $53 \mathrm{mg} \mathrm{O} / \mathrm{L})$. 


\begin{tabular}{|c|c|c|c|c|c|}
\hline & & & Abiotic & $(\mathrm{mM} / \mathrm{h})$ & \\
\hline Reactors treating & 0.04 & $1.4 \mathrm{E}-04$ & 3.3E-06 & $1.5 \mathrm{E}-07$ & 5.7E-09 \\
\hline $\begin{array}{l}\text { typical domestic } \\
\text { wastewaters }\end{array}$ & 0.07 & $2.8 \mathrm{E}-04$ & $6.5 \mathrm{E}-06$ & 3.0E-07 & $1.1 \mathrm{E}-08$ \\
\hline & 0.4 & $1.4 \mathrm{E}-03$ & 3.3E-05 & $1.5 \mathrm{E}-06$ & 5.7E-08 \\
\hline & 0.7 & $2.8 \mathrm{E}-03$ & $6.5 \mathrm{E}-05$ & $3.0 \mathrm{E}-06$ & $1.1 \mathrm{E}-07$ \\
\hline & 3.6 & $1.4 \mathrm{E}-02$ & 3.3E-04 & $1.5 \mathrm{E}-05$ & 5.7E-07 \\
\hline & 7.1 & $2.8 \mathrm{E}-02$ & $6.5 \mathrm{E}-04$ & $3.0 \mathrm{E}-05$ & $1.1 \mathrm{E}-06$ \\
\hline Nitritation & 14.3 & 5.7E-02 & $1.3 \mathrm{E}-03$ & $6.1 \mathrm{E}-05$ & $2.3 \mathrm{E}-06$ \\
\hline & 21.4 & 8.5E-02 & 2.0E-03 & 9.1E-05 & $3.4 \mathrm{E}-06$ \\
\hline & 28.6 & $1.1 \mathrm{E}-01$ & 2.6E-03 & $1.2 \mathrm{E}-04$ & 4.6E-06 \\
\hline & 35.7 & $1.4 \mathrm{E}-01$ & 3.3E-03 & $1.5 \mathrm{E}-04$ & 5.7E-06 \\
\hline & 50 & 2.0E-01 & 4.6E-03 & 2.1E-04 & 8.0E-06 \\
\hline & & 5 & 6 & 7 & 8 \\
\hline
\end{tabular}

Figure S5. Predictions of abiotic $\mathrm{N}_{2} \mathrm{O}$ production rates $\left(\mathrm{r}_{\mathrm{N} 2 \mathrm{O}}\right)$ under operational conditions in

56 reactors treating typical domestic wastewaters $\left(0.007 \mathrm{mM} \mathrm{NH}_{2} \mathrm{OH}, 0.04-0.4 \mathrm{mM} \mathrm{NO}_{2}^{-}\right)$and

57 nitritation reactors $\left(0.007 \mathrm{mM} \mathrm{NH}_{2} \mathrm{OH}, 0.7-50 \mathrm{mM} \mathrm{NO}_{2}{ }^{-}\right) \cdot \mathrm{r}_{\mathrm{N} 2 \mathrm{O}}$ was calculated based on the

58 equation of $\mathrm{r}_{\mathrm{N} 2 \mathrm{O}}=k \cdot\left[\mathrm{HNO}_{2}\right] \cdot\left[\mathrm{NH}_{2} \mathrm{OH}\right]$. 
Table S1. Abiotic batch experiments conditions. The targeted initial substrate concentrations are duplicate.

\begin{tabular}{|c|c|c|c|c|c|c|c|c|}
\hline Experiment & Reaction types & $\mathrm{NH}_{2} \mathrm{OH}(\mathrm{mM})$ & $\mathrm{NO}_{2}^{-}(\mathrm{mM})$ & $\begin{array}{l}\mathrm{FeCl}_{3} \\
(\mathrm{mM})\end{array}$ & $\begin{array}{l}\mathrm{FeSO}_{4} \\
(\mathrm{mM})\end{array}$ & $\mathrm{pH}$ & $\begin{array}{c}\mathrm{DO} \\
(\mathrm{mg} \\
\left.\mathrm{O}_{2} / \mathrm{L}\right)\end{array}$ & $\begin{array}{c}\text { Deionized } \\
\text { water }\left(\mathrm{diH}_{2} \mathrm{O}\right) / \\
\text { synthetic } \\
\text { medium }\end{array}$ \\
\hline \multirow{24}{*}{ Scenario 1} & \multirow{11}{*}{$\begin{array}{c}\mathrm{NH}_{2} \mathrm{OH} \\
\text { oxidation by } \\
\mathrm{HNO}_{2}\end{array}$} & $0.06 \pm 0.01$ & $13.0 \pm 3.0$ & \multirow{5}{*}{ l } & \multirow{5}{*}{ l } & $4.4 \pm 0.1$ & \multirow{5}{*}{$<1$} & \multirow{5}{*}{$\mathrm{diH}_{2} \mathrm{O}$} \\
\hline & & $0.06 \pm 0.01$ & $16.3 \pm 1.6$ & & & $5.1 \pm 0.3$ & & \\
\hline & & $0.07 \pm 0.01$ & $16.8 \pm 0.7$ & & & $6.1 \pm 0.1$ & & \\
\hline & & 0.07 & 17.1 & & & 7.0 & & \\
\hline & & 0.05 & 16.4 & & & 8.2 & & \\
\hline & & $0.05 \pm 0.01$ & $13.6 \pm 0.7$ & \multirow{2}{*}{ I } & \multirow{2}{*}{ l } & $4.5 \pm 0.03$ & \multirow{2}{*}{$8-8.4$} & \multirow{2}{*}{$\mathrm{diH}_{2} \mathrm{O}$} \\
\hline & & 0.06 & 16.4 & & & 8.0 & & \\
\hline & & $0.05 \pm 0.01$ & $16.3 \pm 0.2$ & \multirow{2}{*}{ l } & \multirow{2}{*}{ l } & $4.7 \pm 0.01$ & \multirow{2}{*}{$<1$} & \multirow{2}{*}{ medium } \\
\hline & & 0.06 & 19.3 & & & 8.0 & & \\
\hline & & $0.05 \pm 0.001$ & $15.9 \pm 0.5$ & \multirow{2}{*}{ l } & \multirow{2}{*}{ I } & $4.6 \pm 0.1$ & \multirow{2}{*}{$8-8.4$} & \multirow{2}{*}{ medium } \\
\hline & & 0.07 & 17.1 & & & 8.0 & & \\
\hline & \multirow{9}{*}{$\begin{array}{c}\mathrm{NH}_{2} \mathrm{OH} \\
\text { disproportiona } \\
\text { tion and } \\
\text { oxidation by } \\
\mathrm{O}_{2}\end{array}$} & 0.06 & \multirow{4}{*}{ l } & \multirow{4}{*}{ l } & \multirow{4}{*}{ l } & 4.1 & \multirow{4}{*}{$<1$} & \multirow{4}{*}{$\mathrm{diH}_{2} \mathrm{O}$} \\
\hline & & 0.05 & & & & 6.2 & & \\
\hline & & 0.05 & & & & 8.0 & & \\
\hline & & 0.05 & & & & 8.9 & & \\
\hline & & 0.06 & I & I & 1 & 8.0 & $8-8.4$ & $\mathrm{diH}_{2} \mathrm{O}$ \\
\hline & & 0.05 & \multirow{2}{*}{ l } & \multirow{2}{*}{ l } & \multirow{2}{*}{ l } & 4.0 & \multirow{2}{*}{$<1$} & \multirow{2}{*}{ medium } \\
\hline & & 0.06 & & & & 8.0 & & \\
\hline & & 0.06 & \multirow{2}{*}{ l } & \multirow{2}{*}{ l } & 1 & 4.1 & 884 & medium \\
\hline & & 0.05 & & & 1 & 8.0 & $0-0.4$ & mecumant \\
\hline & $\begin{array}{c}\mathrm{NH}_{2} \mathrm{OH} \\
\text { oxidation by } \\
\mathrm{Fe}^{3+}\end{array}$ & 0.05 & l & 0.09 & l & 4.3 & $<1$ & $\mathrm{diH}_{2} \mathrm{O}$ \\
\hline & $\mathrm{HNO}_{2}$ & & $13.2 \pm 0.7$ & & $\begin{array}{c}0.50 \pm \\
0.21 \\
\end{array}$ & $4.4 \pm 0.002$ & & \\
\hline & $\begin{array}{c}\text { reduction by } \\
\mathrm{Fe}^{2+}\end{array}$ & l & 19.1 & l & 0.26 & 6.4 & $<1$ & $\mathrm{diH}_{2} \mathrm{O}$ \\
\hline & & & 17.1 & & 0.18 & 8.2 & & \\
\hline & $\mathrm{NH}_{2} \mathrm{OH}$ & $0 \rightarrow 0.01 \rightarrow 0.06$ & $0 \rightarrow 3.9 \rightarrow 41.2$ & I & l & $9 \rightarrow 6.4 \rightarrow 5.3$ & $<1$ & $\mathrm{diH}_{2} \mathrm{O}$ \\
\hline Scenario 2 & $\begin{array}{c}\text { oxidation by } \\
\mathrm{HNO}_{2}\end{array}$ & $0 \rightarrow 0.05 \rightarrow 0.11$ & $0 \rightarrow 21.4 \rightarrow 28.6$ & I & l & $\begin{aligned} 7.7 & \rightarrow 7.5 \rightarrow 7.1 \\
& \rightarrow 7.6\end{aligned}$ & $<1$ & medium \\
\hline
\end{tabular}




\begin{tabular}{|c|c|c|c|c|c|c|c|c|} 
& $0 \rightarrow 0.04 \rightarrow 0.07$ & $0 \rightarrow 6.8 \rightarrow 37.9$ & $/$ & $/$ & $\begin{array}{c}8.6 \rightarrow 8.3 \rightarrow 7.9 \\
\rightarrow 6.8 \rightarrow 6\end{array}$ & $<1$ & medium \\
\hline & $/$ & 21.4 & 0.03 & $/$ & $\begin{array}{c}8.5 \rightarrow 7.6 \rightarrow 8.5 \\
\rightarrow 5.8 \rightarrow 5.1\end{array}$ & $<1$ & $\operatorname{diH}_{2} \mathrm{O}$ \\
\hline $\begin{array}{c}\mathrm{HNO}_{2} \\
\text { reduction by } \\
\mathrm{Fe}^{2+}\end{array}$ & $/$ & 20.3 & 0.03 & $/$ & $9.1 \rightarrow 5.3$ & $<1$ & $\operatorname{diH}_{2} \mathrm{O}$ \\
\cline { 2 - 9 } & $/$ & 17.1 & 0.12 & $/$ & $7.6 \rightarrow 6.8 \rightarrow 5.8$ & $<1$ & medium \\
\hline
\end{tabular}

63 


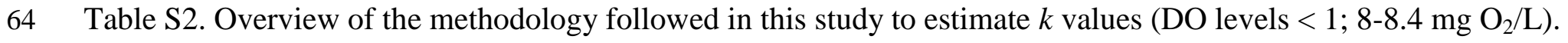

\begin{tabular}{|c|c|c|c|c|c|c|c|c|c|c|}
\hline \multirow[b]{2}{*}{ Timeline } & \multicolumn{2}{|c|}{ Reaction } & \multicolumn{3}{|c|}{ Experimental conditions } & \multirow[b]{2}{*}{$\begin{array}{l}\text { Ref. } \\
\text { in text }\end{array}$} & \multicolumn{2}{|c|}{ Reaction kinetics } & \multirow[b]{2}{*}{$\begin{array}{l}\text { Comments / } \\
\text { Assumptions }\end{array}$} & \multirow[b]{2}{*}{ Output } \\
\hline & Number & Stoichiometry & $\begin{array}{c}\text { Dataset } \\
\text { (measured) }\end{array}$ & $\begin{array}{l}\text { diH2O/ } \\
\text { synthetic } \\
\text { medium }\end{array}$ & $\mathrm{pH}$ & & $\begin{array}{l}\text { Data and } \\
\text { assumed } \\
\text { reactions }\end{array}$ & $\begin{array}{c}\text { Data fit and } \\
k \text {-value } \\
\text { estimated } \\
\end{array}$ & & \\
\hline Step_1 & $\begin{array}{l}\text { Reaction } \\
(4) \mathrm{HNO}_{2} \\
\text { reduction } \\
\text { by } \mathrm{Fe}^{2+}\end{array}$ & $\begin{array}{l}2 \mathrm{HNO}_{2}+4 \mathrm{Fe}^{2+} \\
+4 \mathrm{H}^{+} \rightarrow 4 \mathrm{Fe}^{3+} \\
+\mathrm{N}_{2} \mathrm{O}+3 \mathrm{H}_{2} \mathrm{O}\end{array}$ & $\begin{array}{c}\mathrm{HNO}_{2}, \mathrm{Fe}^{2+} \\
\mathrm{Fe}^{3+}, \mathrm{N}_{2} \mathrm{O}\end{array}$ & $\mathrm{diH}_{2} \mathrm{O}$ & $\begin{array}{l}4.4 / \\
6 / 8\end{array}$ & $\begin{array}{l}\text { Fig } \\
\text { S2 } \\
\text { S3 }\end{array}$ & $\begin{array}{c}\text { Data_Step_1 } \\
\left(\mathrm{rN}_{2} \mathrm{O}, \mathrm{HNO}_{2},\right. \\
\left.\mathrm{Fe}^{2+}, \mathrm{Fe}^{3+}\right) \\
(\mathrm{pH}=4.4) \\
= \\
\text { [Reaction_(4)] }\end{array}$ & $\begin{array}{c}\text { Data_Step_1 } \\
= \\
k_{(4)} \cdot\left[\mathrm{HNO}_{2}\right]^{2} \cdot[ \\
\left.\left.\mathrm{Fe}^{2+}\right]^{4}\right)\end{array}$ & $\begin{array}{c}\text { Incomplete recovery } \\
\text { of } \mathrm{N}_{2} \mathrm{O} \text { from the } \\
\text { stoichiometric } \mathrm{Fe}^{2+} \\
\text { oxidation } \\
\text { at } \mathrm{pH}=6.4(49 \%) \\
\text { and } \mathrm{pH}=8.2(12 \%) \text {. }\end{array}$ & $\begin{array}{c}k_{(4)} \text { could not be } \\
\text { estimated at } \mathrm{pH} \text { values } \\
\text { higher than } 4.4 \\
\text { Reaction (4) will not a } \\
\text { big impact at neutral pH } \\
\text { values. }\end{array}$ \\
\hline Step_2 & $\begin{array}{c}\text { Reaction } \\
(3) \\
\mathrm{NH}_{2} \mathrm{OH} \\
\text { dispropor } \\
\text { tionation } \\
\text { Reaction } \\
(2) \\
\mathrm{NH}_{2} \mathrm{OH} \\
\text { oxidation } \\
\text { by } \mathrm{O}_{2}\end{array}$ & $\begin{array}{c}4 \mathrm{NH}_{2} \mathrm{OH} \rightarrow \\
2 \mathrm{NH}_{3}+\mathrm{N}_{2} \mathrm{O}+ \\
\quad 3 \mathrm{H}_{2} \mathrm{O} \\
\\
2 \mathrm{NH}_{2} \mathrm{OH}+\mathrm{O}_{2} \\
\rightarrow \mathrm{N}_{2} \mathrm{O}+3 \mathrm{H}_{2} \mathrm{O}\end{array}$ & $\begin{array}{l}\mathrm{NH}_{2} \mathrm{OH} \\
\mathrm{N}_{2} \mathrm{O}\end{array}$ & $\begin{array}{l}\mathrm{diH}_{2} \mathrm{O} ; \\
\text { medium }\end{array}$ & $\begin{array}{l}4 / 6 / \\
8 / 9\end{array}$ & Fig 1 & $\begin{array}{c}\text { Data_Step_2 } \\
\left(\mathrm{rN}_{2} \mathrm{O}, \mathrm{NH}_{2} \mathrm{OH}\right) \\
= \\
{[\text { Reaction_(2) }} \\
\text { Reaction_(3) }\end{array}$ & $\begin{array}{c}\text { Data_Step_2 } \\
\approx \\
\begin{array}{c}\text { Reaction_(3) } \\
=\end{array} \\
k_{l} \cdot\left[\mathrm{NH}_{2} \mathrm{OH}\right]^{4} \\
\text { (Eq. 12) }\end{array}$ & $\begin{array}{l}\text { The calculated } \mathrm{N}_{2} \mathrm{O} \\
\text { yield (relative to the } \\
\text { amount of } \mathrm{NH}_{2} \mathrm{OH} \\
\text { oxidized) for } \\
\text { Reaction (3) was } \\
\text { much closer to the } \\
\text { theoretical than for } \\
\text { Reaction (2) } \\
\mathrm{r}_{\mathrm{NH} 2 \mathrm{OH}} \text { and } \mathrm{r}_{\mathrm{N} 2 \mathrm{O}} \text { in } \\
\text { synthetic medium } \\
\text { were } 2-22 \text { times } \\
\text { higher than in diH } \mathrm{H}_{2} \mathrm{O}\end{array}$ & $\begin{array}{c}\mathrm{NH}_{2} \mathrm{OH} \\
\text { disproportionation } \\
\text { (Reaction 3) shows } \\
\text { higher rates than } \\
\mathrm{NH}_{2} \mathrm{OH} \text { oxidation } \\
\text { (Reaction 2). } \\
\\
\text { The chemical medium } \\
\text { enhances } \mathrm{N}_{2} \mathrm{O} \\
\text { production compared to } \\
\text { diH2O (at pH = 8). }\end{array}$ \\
\hline Step_3 & $\begin{array}{l}\text { Reaction } \\
(5) \\
\mathrm{NH}_{2} \mathrm{OH} \\
\text { oxidation } \\
\text { by } \mathrm{Fe}^{3+}\end{array}$ & $\begin{array}{c}4 \mathrm{Fe}^{3+}+ \\
2 \mathrm{NH}_{2} \mathrm{OH} \rightarrow \\
4 \mathrm{Fe}^{2+}+\mathrm{N}_{2} \mathrm{O}+ \\
\mathrm{H}_{2} \mathrm{O}+4 \mathrm{H}^{+}\end{array}$ & $\begin{array}{l}\mathrm{NH}_{2} \mathrm{OH} \\
\mathrm{Fe}^{2+}, \mathrm{Fe}^{3+} \\
\mathrm{N}_{2} \mathrm{O}\end{array}$ & $\mathrm{diH}_{2} \mathrm{O}$ & 4.3 & $\begin{array}{l}\text { Fig } \\
\text { S4 }\end{array}$ & $\begin{array}{c}\text { Data_Step_3 } \\
\left(\mathrm{rN}_{2} \mathrm{O}, \mathrm{NH}_{2} \mathrm{OH},\right. \\
\left.\mathrm{Fe}^{3+}\right) \\
= \\
{[\text { Reaction_(5) }} \\
\text { Reaction_(3) }^{+}\end{array}$ & I & $\begin{array}{l}\text { Incomplete recovery } \\
\text { of } \mathrm{N}_{2} \mathrm{O} \text { from the } \\
\text { stoichiometric } \\
\mathrm{NH}_{2} \mathrm{OH} \text { oxidation at } \\
\mathrm{pH}=4.3(66 \%)\end{array}$ & $\begin{array}{c}k_{(5)} \text { could not be } \\
\text { estimated even at low } \\
\mathrm{pH} \text { where Fe is more } \\
\text { stable. } \\
\text { Reaction (5) will not a } \\
\text { big impact at neutral pH } \\
\text { values. }\end{array}$ \\
\hline Step_4 & $\begin{array}{l}\text { Reaction } \\
\quad(1) \\
\mathrm{NH}_{2} \mathrm{OH} \\
\text { oxidation }\end{array}$ & $\begin{array}{l}\mathrm{NH}_{2} \mathrm{OH}+ \\
\mathrm{HNO}_{2} \rightarrow \mathrm{N}_{2} \mathrm{O} \\
\quad+2 \mathrm{H}_{2} \mathrm{O}\end{array}$ & $\begin{array}{c}\mathrm{NH}_{2} \mathrm{OH} \\
\mathrm{HNO}_{2}, \mathrm{~N}_{2} \mathrm{O}\end{array}$ & $\mathrm{diH}_{2} \mathrm{O}$ & $\begin{array}{l}4.5 / \\
5 / 6 / \\
7 / 8\end{array}$ & $\begin{array}{l}\text { Fig } 2 \text {, } \\
\quad 3\end{array}$ & $\begin{array}{c}\text { Data_Step_4 } \\
\left(\mathrm{rN}_{2} \mathrm{O}, \mathrm{NH}_{2} \mathrm{OH}\right. \\
\left.\mathrm{HNO}_{2}\right) \\
=\end{array}$ & $\begin{array}{c}\text { Reaction_(1) } \\
= \\
\text { \{Data_Step_4 } \\
\text { - }\end{array}$ & $\begin{array}{l}\text { Kinetics of Reaction } \\
\text { (1) were calculated } \\
\text { assuming only } \\
\text { Reaction (3) }\end{array}$ & $\begin{array}{l}k_{(3)} \text { was estimated as a } \\
\text { function of } \mathrm{pH} \text { : } \\
\left(k_{3 \_\mathrm{pH}}=8272.5 \mathrm{e}^{-1.1 \mathrm{pH}}, \mathrm{R}^{2}\right.\end{array}$ \\
\hline
\end{tabular}




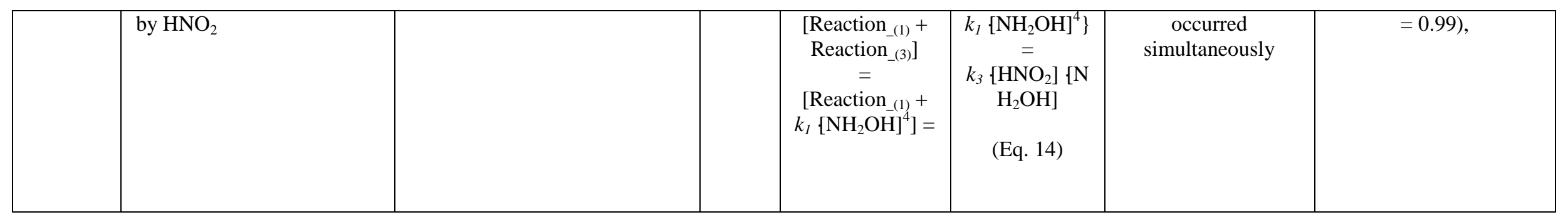


65 Table S3. Comparison of different rate equations to describe the oxidation of $\mathrm{NH}_{2} \mathrm{OH}$ by $\mathrm{HNO}_{2}$ in

66 Scenario $1\left(\mathrm{pH}=4.5,5,6,7\right.$ and 8; $\left.\mathrm{diH}_{2} \mathrm{O} ; \mathrm{DO}<1 \mathrm{mg} \mathrm{O}_{2} / \mathrm{L} ; \mathrm{T}=25^{\circ} \mathrm{C}\right)$. The $k$ values were retrieved

67 by fitting experimental data to model predictions by minimizing normalized root mean square error

68 (NRMSE).

\begin{tabular}{|c|c|c|c|c|c|}
\hline Equation & $\begin{array}{c}\mathrm{r}_{\mathrm{N} 2 \mathrm{OR}}= \\
\mathrm{k}_{0} \cdot\left[\mathrm{NO}_{2}^{-}\right] \\
\cdot\left[\mathrm{NH}_{2} \mathrm{OH}\right]\end{array}$ & $\begin{array}{c}\mathrm{r}_{\mathrm{N} 2 \mathrm{OR}}= \\
\mathrm{k}_{0} \cdot\left[\mathrm{HNO}_{2}\right] \cdot\left[\mathrm{NH}_{2}\right. \\
\mathrm{OH}]\end{array}$ & $\begin{array}{c}\mathrm{r}_{\mathrm{N} 2 \mathrm{OR}}= \\
\mathrm{k}_{0} \cdot\left[\mathrm{H}^{+}\right] \cdot\left[\mathrm{HNO}{ }_{2}\right. \\
] \cdot\left[\mathrm{NH}_{2} \mathrm{OH}\right]\end{array}$ & $\begin{array}{c}\mathrm{r}_{\mathrm{N} 2 \mathrm{OR}}=\mathrm{k}_{0} \cdot \mathrm{e}^{\wedge}\left(\mathrm{k}_{1}\right. \\
\cdot \mathrm{pH}) \cdot\left[\mathrm{NO}_{2}^{-}\right] \\
\cdot\left[\mathrm{NH}_{2} \mathrm{OH}\right]\end{array}$ & $\begin{array}{c}\mathrm{r}_{\mathrm{N} 2 \mathrm{OR}}=\mathrm{k}_{0} \cdot \mathrm{e}^{\wedge}\left(\mathrm{k}_{1}\right. \\
\cdot \mathrm{pH}) \cdot\left[\mathrm{HNO}_{2}\right] \\
\cdot\left[\mathrm{NH}_{2} \mathrm{OH}\right]\end{array}$ \\
\hline Reference & $\begin{array}{l}\text { Harper et al. } \\
\quad(2015)\end{array}$ & $\begin{array}{c}\text { Döring and } \\
\text { Gehlen (1961) }\end{array}$ & $\begin{array}{c}\text { Döring and } \\
\text { Gehlen (1961) }\end{array}$ & This study & This study \\
\hline $\mathrm{k}_{0}(\mathrm{~L} / \mathrm{mmol} / \mathrm{h})$ & 0.20 & 44.9 & $9.4 \times 10^{5 *}$ & $1.6 \times 10^{6}$ & 867.7 \\
\hline $\mathrm{k}_{1}$ & I & l & I & -3.0 & -0.68 \\
\hline NRMSE & 0.49 & 0.058 & 0.068 & 0.014 & 0.015 \\
\hline
\end{tabular}

69

${ }^{*} L^{2} / \mathrm{mmol}^{2} / \mathrm{h}$ 
Table S4. Summary of experimental conditions and calculated kinetic rates of abiotic reactions in Scenario1 and literature.

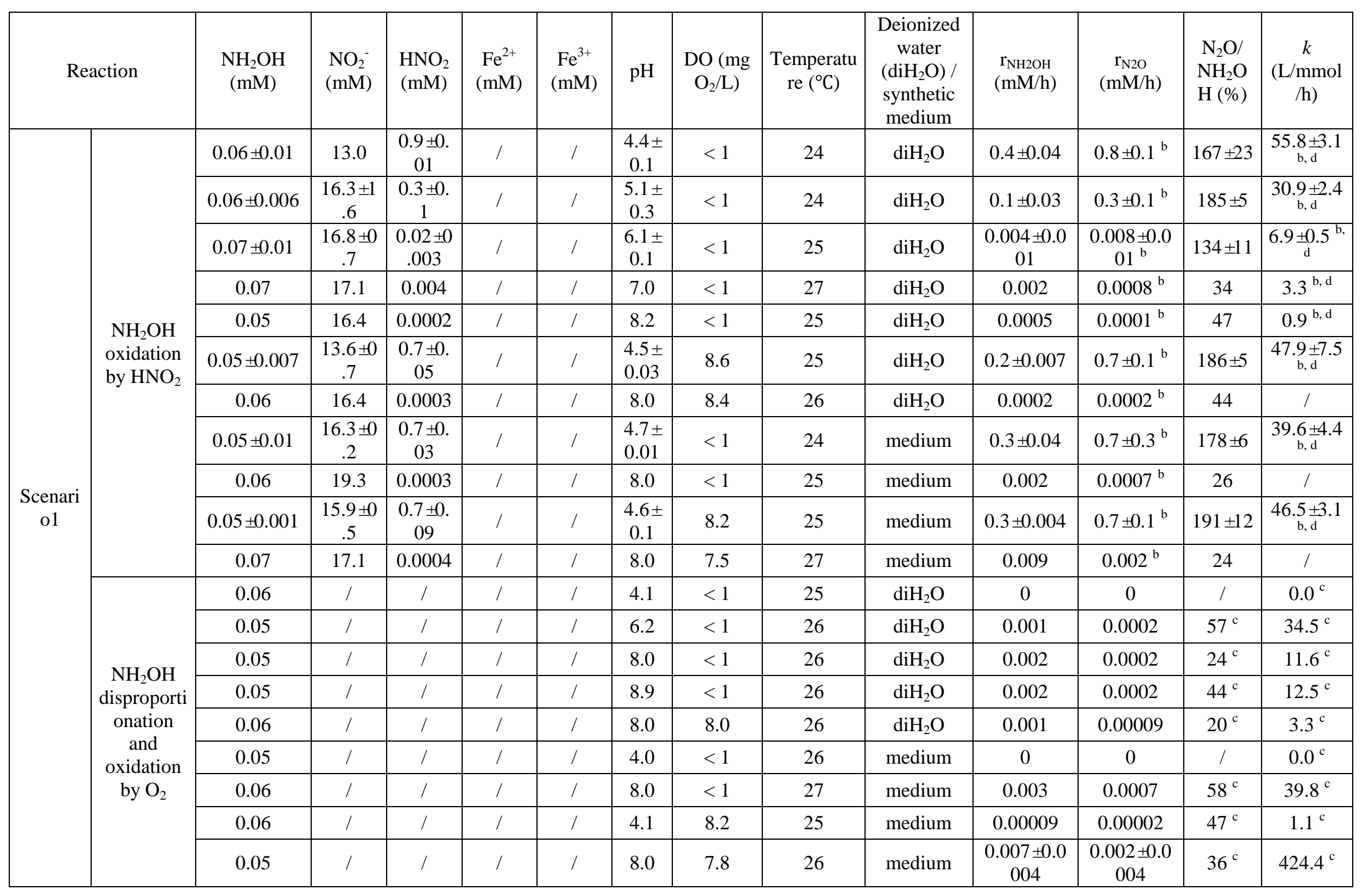




\begin{tabular}{|c|c|c|c|c|c|c|c|c|c|c|c|c|c|c|}
\hline & \multirow{3}{*}{$\begin{array}{c}\text { Iron- } \\
\text { mediated } \\
\text { reduction } \\
\text { of } \mathrm{HNO}_{2}\end{array}$} & I & $\begin{array}{c}13.2 \pm 0 \\
.7 \\
\end{array}$ & $\begin{array}{c}0.8 \pm 0 . \\
09\end{array}$ & $\begin{array}{c}0.5 \pm 0 . \\
2 \\
\end{array}$ & I & 4.4 & $<1$ & 23 & $\mathrm{diH}_{2} \mathrm{O}$ & $0.3 \pm 0.03$ & $0.2 \pm 0.009$ & $98 \pm 3$ & $\begin{array}{c}46.4 \pm \\
4.1\end{array}$ \\
\hline & & I & 19.1 & 0.001 & 0.3 & I & 6.4 & $<1$ & 25 & $\mathrm{diH}_{2} \mathrm{O}$ & 0.02 & 0.002 & 49 & I \\
\hline & & 1 & 17.1 & 0.0002 & 0.2 & 1 & 8.2 & $<1$ & 24 & $\mathrm{diH}_{2} \mathrm{O}$ & 0.03 & 0.002 & 12 & 1 \\
\hline & $\begin{array}{c}\mathrm{NH} 2 \mathrm{OH} \\
\text { oxidation } \\
\text { by } \mathrm{Fe}^{3+}\end{array}$ & 0.05 & I & I & I & 0.09 & 4.3 & $<1$ & 24 & $\mathrm{diH}_{2} \mathrm{O}$ & 0.003 & $0.001^{b}$ & 66 & I \\
\hline $\begin{array}{c}\text { Harper } \\
\text { et al. } \\
(2015)\end{array}$ & \multirow{4}{*}{$\begin{array}{c}\mathrm{NH}_{2} \mathrm{OH} \\
\text { oxidation } \\
\text { by } \mathrm{HNO}_{2}\end{array}$} & $0.007-1.4^{\mathrm{a}}$ & $28.6^{\mathrm{a}}$ & $0.006^{\mathrm{a}}$ & $0.01^{\mathrm{a}}$ & I & 7 & aerobic & I & medium $^{\mathrm{e}}$ & I & $0.02-0.7^{\mathrm{a}}$ & I & $0.05^{\mathrm{d}}$ \\
\hline $\begin{array}{c}\text { Terada } \\
\text { et al. } \\
(2017)\end{array}$ & & $0.07-1.4^{\mathrm{a}}$ & $28.6^{\mathrm{a}}$ & $0.006^{\mathrm{a}}$ & $0.01^{\mathrm{a}}$ & I & 7 & $\begin{array}{l}7.11- \\
8.25\end{array}$ & 28 & medium $^{\mathrm{e}}$ & I & $0.05-0.9^{\mathrm{a}}$ & I & I \\
\hline $\begin{array}{c}\text { Soler- } \\
\text { Jofra et } \\
\text { al. } \\
(2016)\end{array}$ & & $0.02^{a}$ & $\begin{array}{c}9.6 / 46 . \\
4^{\mathrm{a}}\end{array}$ & $\begin{array}{l}0.0075 / \\
0.012^{a}\end{array}$ & $0.15^{\mathrm{a}}$ & I & $6.2 / 7$ & aerobic & 30 & medium $^{\mathrm{e}}$ & $0.01 / 0.02^{a}$ & $\begin{array}{c}0.003 / 0.00 \\
6^{\mathrm{a}}\end{array}$ & $22 / 41$ & I \\
\hline $\begin{array}{c}\text { Soler- } \\
\text { Jofra et } \\
\text { al. } \\
(2018)\end{array}$ & & $\underset{\mathrm{a}}{0.004-0.014}$ & $16.4^{\mathrm{a}}$ & $\underset{\mathrm{a}}{0.0004}$ & I & $\begin{array}{c}0.013 \\
\% \\
\text { EDTA- } \\
\mathrm{Fe}^{3+} \\
\end{array}$ & $\begin{array}{c}7.5 \pm \\
0.1\end{array}$ & aerobic & 21 & medium $^{\mathrm{e}}$ & I & $\begin{array}{l}0.002- \\
0.003^{\mathrm{a}}\end{array}$ & $20-40$ & I \\
\hline $\begin{array}{c}\text { Terada } \\
\text { et al. } \\
(2017)\end{array}$ & $\begin{array}{c}\mathrm{NH}_{2} \mathrm{OH} \\
\text { oxidation } \\
\text { by } \mathrm{O}_{2}\end{array}$ & $0.07-1.4^{\mathrm{a}}$ & $28.6^{\mathrm{a}}$ & $0.006^{\mathrm{a}}$ & $0.01^{\mathrm{a}}$ & I & 7 & $\begin{array}{l}7.11- \\
8.25\end{array}$ & 28 & medium $^{\mathrm{e}}$ & I & $0.01^{\mathrm{a}}$ & I & I \\
\hline $\begin{array}{c}\text { Kampsc } \\
\text { hreur et } \\
\text { al. } \\
(2011)\end{array}$ & $\begin{array}{c}\text { Iron- } \\
\text { mediated } \\
\text { reduction } \\
\text { of } \mathrm{HNO}_{2}\end{array}$ & I & $0-43$ & $\underset{\mathrm{a}}{0-0.05}$ & 10 & I & 6.5 & anoxic & 35 & water & I & $0.9^{\mathrm{a}}$ & I & I \\
\hline
\end{tabular}

${ }^{\mathrm{a}}$ Numbers were calculated based on original data in literature.

$72 \quad{ }^{\mathrm{b}} \mathrm{r}_{\mathrm{N} 2 \mathrm{O}}$ and $k$ value of $\mathrm{NH}_{2} \mathrm{OH}$ oxidation by $\mathrm{HNO}_{2}$ and $\mathrm{Fe}^{3+}$ in this study were estimated by substracting $\mathrm{N}_{2} \mathrm{O}$ produced by $\mathrm{NH}_{2} \mathrm{OH}$ disproportionation and/or oxidation by $\mathrm{O}_{2}$.

${ }^{c} \mathrm{~N}_{2} \mathrm{O} / \mathrm{NH}_{2} \mathrm{OH}$ and $k$ value of $\mathrm{NH}_{2} \mathrm{OH}$ disproportionation and/or oxidation by $\mathrm{O}_{2}$ in this study was calculated based on the equation of $\mathrm{X}_{\mathrm{N}_{2} \mathrm{O} / \mathrm{NH}_{2} \mathrm{OH}}=\frac{\mathrm{m}_{\mathrm{N}_{2} \mathrm{O}} \cdot 4}{\mathrm{~m}_{\mathrm{NH}} \mathrm{OH}} \cdot 100 \%$ and $\mathrm{r}_{\mathrm{N} 2 \mathrm{O}}=k \cdot\left[\mathrm{NH}_{2} \mathrm{OH}\right]^{4}$.

${ }^{\mathrm{d}} k$ value of $\mathrm{NH}_{2} \mathrm{OH}$ oxidation by $\mathrm{HNO}_{2}$ in this study was calculated based on the equation of $\mathrm{r}_{\mathrm{N} 2 \mathrm{O}}=k \cdot\left[\mathrm{HNO}_{2}\right] \cdot\left[\mathrm{NH}_{2} \mathrm{OH}\right]$; but $k$ reported in Harper et al. $(2015)$ was based on $\mathrm{r}_{\mathrm{N} 2 \mathrm{O}}=k \cdot\left[\mathrm{NO}_{2}^{-}\right] \cdot\left[\mathrm{NH}_{2} \mathrm{OH}\right]$.

${ }^{\mathrm{e}}$ The compositions of synthetic medium in literatures are similar to the one used in our experiments, which are mainly consisted of $\mathrm{KH}_{2} \mathrm{PO} 4$, $\mathrm{MgSO} \cdot 7 \mathrm{H}_{2} \mathrm{O}$,

$\mathrm{CaCl}_{2} \cdot 2 \mathrm{H}_{2} \mathrm{O}$, EDTA, FeSO $\mathrm{F}_{4} \cdot 7 \mathrm{H}_{2} \mathrm{O}$ and trace element solution. The exact concentrations of these chemicals can be found in literatures.

${ }^{\mathrm{f}} k$ value was calculated only for this $\mathrm{pH}$ value based on the equation of $\mathrm{r}_{\mathrm{N} 2 \mathrm{O}}=k \cdot\left[\mathrm{HNO}_{2}\right]^{2} \cdot\left[\mathrm{Fe}^{2+}\right]^{4}\left(\mathrm{~L}^{5} / \mathrm{mmol}^{5} / \mathrm{h}\right)$. 
Table S5. Predictions of abiotic $\mathrm{N}_{2} \mathrm{O}$ production rates and the abiotic contributions to overall $\mathrm{N}_{2} \mathrm{O}$ production in nitritation reactors.

\begin{tabular}{|c|c|c|c|c|c|c|c|c|c|c|c|}
\hline \multirow[b]{2}{*}{ Reference } & \multirow[b]{2}{*}{$\begin{array}{l}\text { Reactor } \\
\text { types }\end{array}$} & \multicolumn{6}{|c|}{ Experimental condition } & \multirow{2}{*}{$\begin{array}{c}\begin{array}{c}\text { Total } \mathrm{N}_{2} \mathrm{O} \\
\text { production }\end{array} \\
\mathrm{r}_{\mathrm{N} 2 \mathrm{O}}(\mathrm{mM} / \mathrm{h})\end{array}$} & \multicolumn{3}{|c|}{ Abiotic $\mathrm{N}_{2} \mathrm{O}$ production } \\
\hline & & $\mathrm{T}\left({ }^{\circ} \mathrm{C}\right)$ & $\begin{array}{c}\mathrm{DO} \\
(\mathrm{mg} \\
\left.\mathrm{O}_{2} / \mathrm{L}\right)\end{array}$ & $\mathrm{pH}$ & $\begin{array}{l}\operatorname{ALR}^{a} \\
(\mathrm{~g} / \mathrm{L} / \mathrm{d})\end{array}$ & $\begin{array}{l}\mathrm{NO}_{2}^{-\mathrm{a}} \\
(\mathrm{mM})\end{array}$ & $\begin{array}{c}\mathrm{HNO}_{2}{ }^{\mathrm{a}} \\
(\mathrm{mM})\end{array}$ & & $\begin{array}{c}k^{\mathrm{b}} \\
(\mathrm{L} / \mathrm{mmol} / \mathrm{h})\end{array}$ & $\begin{array}{l}\mathrm{r}_{\mathrm{N} 2 \mathrm{O}}{ }^{\mathrm{c}} \\
(\mathrm{mM} / \mathrm{h})\end{array}$ & $\begin{array}{c}\text { Fraction of } \\
\text { abiotic pathway } \\
\text { to total } \mathrm{N}_{2} \mathrm{O} \\
\text { production }(\%)\end{array}$ \\
\hline $\begin{array}{c}\text { Kong et al., } \\
2013^{7}\end{array}$ & $\begin{array}{l}\text { Lab-scale, } \\
\text { PN, SBR, } \\
\text { flocs }\end{array}$ & $32 \pm 0.5$ & 1 & $6-7.5$ & 3 & $\begin{array}{c}17.7 \pm \\
0.9\end{array}$ & $\begin{array}{c}8.5 \pm \\
0.41 \times 10^{-3}\end{array}$ & 0.036 & 4.67 & $2.80 \times 10^{-4}$ & 0.79 \\
\hline $\begin{array}{c}\text { Rathnayake et } \\
\text { al., } 2013^{8}\end{array}$ & $\begin{array}{l}\text { Lab-scale, } \\
\text { PN, SBR, } \\
\text { granules }\end{array}$ & l & $2.0 \pm 0.3$ & $7.4-7.8$ & $\begin{array}{c}1.03 \pm \\
0.06\end{array}$ & $\begin{array}{c}13.0 \pm \\
2.1\end{array}$ & $\begin{array}{c}5.9 \pm \\
0.94 \times 10^{-4}\end{array}$ & 0.012 & 1.94 & $8.10 \times 10^{-6}$ & 0.07 \\
\hline $\begin{array}{c}\text { de Graaff et } \\
\text { al., } 2010^{9}\end{array}$ & $\begin{array}{l}\text { Lab-scale, } \\
\text { PN, CFR, } \\
\text { flocs }\end{array}$ & 25 & $\begin{array}{c}4.1 \pm \\
0.73\end{array}$ & $\begin{array}{l}6.8 \pm \\
0.33\end{array}$ & 0.52 & 35.7 & $1.0 \times 10^{-2}$ & 0.015 & 4.67 & $3.40 \times 10^{-4}$ & 2.31 \\
\hline $\begin{array}{l}\text { Okabe et al., } \\
2011^{10}\end{array}$ & $\begin{array}{l}\text { Lab-scale, } \\
\text { PN, CFR, } \\
\text { biofilm }\end{array}$ & 35 & $<2$ & $\begin{array}{c}7.8 \pm \\
0.1\end{array}$ & $3.5-4.1$ & $\begin{array}{c}5.7 \pm \\
12.9\end{array}$ & $\begin{array}{c}3.4- \\
7.7 \times 10^{-4}\end{array}$ & 0.006 & 1.55 & $6.20 \times 10^{-6}$ & 0.10 \\
\hline $\begin{array}{l}\text { Kong et al., } \\
2013^{11}\end{array}$ & $\begin{array}{l}\text { Lab-scale, } \\
\text { PN, SBBR, } \\
\text { biofilm }\end{array}$ & $35 \pm 1$ & $<1.5$ & $7.0-7.5$ & 1.25 & 16.4 & $3.5 \times 10^{-3}$ & 0.028 & 2.85 & $7.10 \times 10^{-5}$ & 0.26 \\
\hline $\begin{array}{l}\text { Kampschreur } \\
\text { et al., } 2008^{12}\end{array}$ & $\begin{array}{l}\text { Full-scale, } \\
\text { PN, } \\
\text { SHARON, } \\
\text { flocs }\end{array}$ & $32-33$ & 2.5 & $6.55-7$ & 6.5 & 36.1 & $1.8 \times 10^{-2}$ & 0.164 & 4.67 & $6.00 \times 10^{-4}$ & 0.36 \\
\hline $\begin{array}{l}\text { Desloover et } \\
\text { al., } 2011^{13}\end{array}$ & $\begin{array}{l}\text { Full-scale, } \\
\text { PN, SBR, } \\
\quad \text { flocs }\end{array}$ & 36 & $\begin{array}{c}0.75 \pm \\
0.01\end{array}$ & $\begin{array}{c}7.5 \pm \\
0.1\end{array}$ & $\begin{array}{c}0.18- \\
0.22\end{array}$ & $8.2 \pm 1.8$ & $\begin{array}{c}1.1 \pm \\
0.23 \times 10^{-3}\end{array}$ & $0.014-0.022$ & 2.16 & $1.60 \times 10^{-5}$ & 0.08 \\
\hline
\end{tabular}

82 Abbreviation: Partial Nitritation (PN); Sequencing Batch Reactor (SBR); Continuous Flow Reactor (CFR); Sequencing Batch Biofilm Reactor (SBBR); Single reactor

83 system for High activity Ammonium Removal Over Nitrite (SHARON); Ammonium Loading Rate (ALR); $\mathrm{N}_{2} \mathrm{O}$ production rate ( $\mathrm{r}_{\mathrm{N} 2 \mathrm{O}}$ ); rate constant $(k)$.

84 a Numbers were calculated based on original data in literatures.

$85{ }^{\mathrm{b}} k$ in literature was calculated based on the function between $k$ and $\mathrm{pH}$ (i.e. $k=8272.5 \mathrm{e}^{-1.1 \mathrm{pH}}$ ) obtained in this study. However, the effect of temperature was not 86 corrected during $k$ calculation.

$87{ }^{\mathrm{e}}$ Estimated abiotic $\mathrm{r}_{\mathrm{N} 2 \mathrm{O}}$ was calculated based on the equation of $\mathrm{r}_{\mathrm{N} 2 \mathrm{O}}=k \cdot\left[\mathrm{HNO}_{2}\right] \cdot\left[\mathrm{NH}_{2} \mathrm{OH}\right]$. As $\mathrm{NH}_{2} \mathrm{OH}$ was not measured in these studies, the concentration of $88 \mathrm{NH}_{2} \mathrm{OH}$ was assumed at $0.007 \mathrm{mM}$ for abiotic $\mathrm{r}_{\mathrm{N} 2 \mathrm{O}}$ calculation. 


\section{Section $1-\mathrm{NH}_{2} \mathrm{OH}$ analysis}

The $\mathrm{NH}_{2} \mathrm{OH}$ concentration was measured following the protocol proposed by Frear and Burrell (1955) and Soler-Jofra et al. (2016):

1. Add $1.6 \mathrm{~mL}$ of the filtered sample containing $\mathrm{NH}_{2} \mathrm{OH}$ in the range of $0-2.1 \mathrm{mg} \mathrm{N} / \mathrm{L}$ to $5 \mathrm{~mL}$ test tube, follow with $0.2 \mathrm{~mL}$ of $0.1 \mathrm{~g} / \mathrm{mL}$ sulfamic acid to and mix.

2. Add $1 \mathrm{~mL}$ of $0.05 \mathrm{M}$ phosphate buffer, $0.2 \mathrm{~mL}$ of $12 \mathrm{wt} \%$ trichloroacetic acid and $1 \mathrm{~mL}$ of $1 \%$ 8-quinolinol (w/v), then swirl gently.

3. Add add $1.0 \mathrm{~mL}$ of $1.0 \mathrm{M}$ sodium carbonate solution, shake vigorously.

4. Heat $1 \mathrm{~min}$ at $100{ }^{\circ} \mathrm{C}$ in a water bath and cool for $15 \mathrm{~min}$, and then read in spectrophotometer at $705 \mu \mathrm{m}$.

5. Carry out simultaneously a blank by replacing the sample volume by the same volume of demineralized.

Additionally, $0.1 \mathrm{~mL}$ of $3.5 \mathrm{mg} \mathrm{N} / \mathrm{L} \mathrm{NH}_{2} \mathrm{OH}$ stock solution was added in one of triplicate bulk samples as the internal standard to verify the measuring accuracy. Recovery efficiency of $93 \pm 6 \%$ of the added internal standard $(n=12)$ indicated that the adopted pretreatment and measurement procedures were applicable and precise for $\mathrm{NH}_{2} \mathrm{OH}$ quantification of our samples. 


\section{Section 2 - Measurement of the sensitivity and response time of sensors}

107 The $\mathrm{pH}$ sensitivity of $\mathrm{N}_{2} \mathrm{O}$ sensor was measured at stepwise increases or decreases of $\mathrm{pH}$ values by 108 sequentially spiking alkali or acid (Figure S6). The signal changes in response to $\mathrm{pH}$ changes were

109 below $0.2 \%$, indicating a low $\mathrm{pH}$ sensitivity of the $\mathrm{N}_{2} \mathrm{O}$ sensor. In addition, we performed tests at

110 different DO levels and stir intensities by spiking oxygen saturated liquid or changing stirring rates.

111 No significant changes of $\mathrm{N}_{2} \mathrm{O}$ signal were observed.

112 The response times of $\mathrm{N}_{2} \mathrm{O} / \mathrm{pH} / \mathrm{DO}$ sensors were detected by counting the interval required by the 113 output signal of sensors to display a change in the applied $\mathrm{N}_{2} \mathrm{O} / \mathrm{pH} / \mathrm{DO}$ concentrations. The 114 measured response times of $\mathrm{N}_{2} \mathrm{O}, \mathrm{pH}$, and DO sensors were $<30 \mathrm{~s}, \leq 45 \mathrm{~s}$, and $\leq 45 \mathrm{~s}$, respectively.

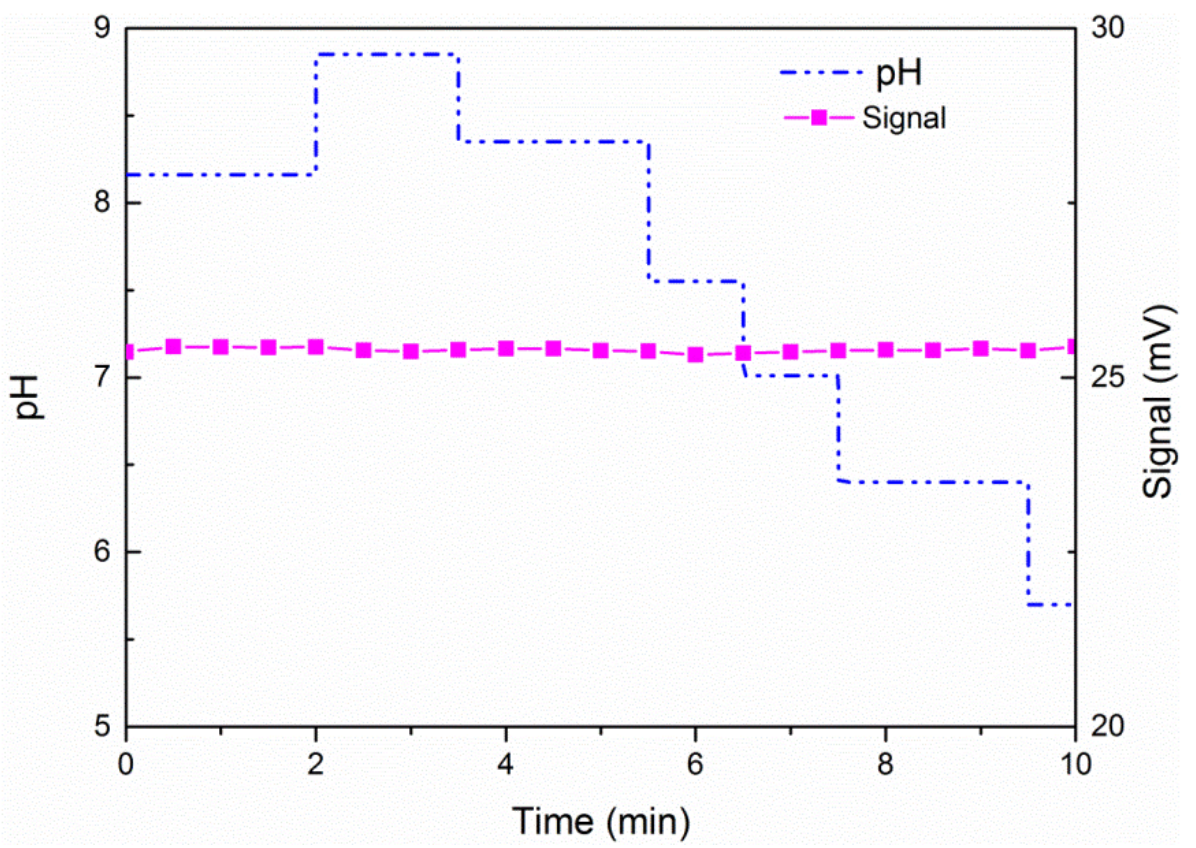

115

116 Figure $\mathrm{S} 6$. The sensitivity of $\mathrm{N}_{2} \mathrm{O}$ sensor towards $\mathrm{pH}$ changes. 


\section{Reference}

118 (1) Harper, W. F.; Takeuchi, Y.; Riya, S.; Hosomi, M.; Terada, A. Novel abiotic reactions increase nitrous oxide production during partial nitrification: Modeling and experiments. Chem. Eng. J. 2015, 281, 1017-1023.

(2) Döring, C.; Gehlen, H. Über die Kinetik der Reaktion zwischen Hydroxylamin und Salpetriger Säure. J. Inorg. Gen. Chem. 1961, 312 (1-2), 32-44.

(3) Terada, A.; Sugawara, S.; Hojo, K.; Takeuchi, Y.; Riya, S.; Harper, W. F.; Yamamoto, T.; Kuroiwa, M.; Isobe, K.; Katsuyama, C.; Suwa, Y.; Koba, K; Hosomi, M. Hybrid Nitrous Oxide Production from a Partial Nitrifying Bioreactor: Hydroxylamine Interactions with Nitrite. Environ. Sci. Technol. 2017, 51 (5), 2748-2756.

(4) Soler-Jofra, A.; Stevens, B.; Hoekstra, M.; Picioreanu, C.; Sorokin, D.; van Loosdrecht, M. C. M.; Pérez, J. Importance of abiotic hydroxylamine conversion on nitrous oxide emissions during nitritation of reject water. Chem. Eng. J. 2016, 287, 720-726.

(5) Soler-Jofra, A.; Picioreanu, C.; Yu, R.; Chandran, K.; van Loosdrecht, M. C. M.; Pérez, J. Importance of hydroxylamine in abiotic $\mathrm{N} 2 \mathrm{O}$ production during transient anoxia in planktonic axenic Nitrosomonas cultures. Chem. Eng. J. 2018, 335, 756-762.

(6) Kampschreur, M. J.; Kleerebezem, R.; de Vet, W. W. J. M.; van Loosdrecht, M. C. M. Reduced iron induced nitric oxide and nitrous oxide emission. Water Res. 2011, 45 (18), 5945-5952. Kong, Q.; Liang, S.; Zhang, J.; Xie, H.; Miao, M.; Tian, L. N2O emission in a partial nitrification system: Dynamic emission characteristics and the ammonium-oxidizing bacteria community. Bioresour. Technol. 2013, 127, 400-406.

(8) Rathnayake, R. M. L. D.; Song, Y.; Tumendelger, A.; Oshiki, M.; Ishii, S.; Satoh, H.; Toyoda, S.; Yoshida, N.; Okabe, S. Source identification of nitrous oxide on autotrophic partial nitrification in a granular sludge reactor. Water Res. 2013, 47 (19), 7078-7086.

(9) de Graaff, M. S.; Zeeman, G.; Temmink, H.; van Loosdrecht, M. C. M.; Buisman, C. J. N. Long term partial

(10) Okabe, S.; Oshiki, M.; Takahashi, Y.; Satoh, H. Development of long-term stable partial nitrification and

(11) Kong, Q.; Zhang, J.; Miao, M.; Tian, L.; Guo, N.; Liang, S. Partial nitrification and nitrous oxide emission in an

(12) Kampschreur, M. J.; Tan, N. C. G.; Kleerebezem, R.; Picioreanu, C.; Jetten, M. S. M.; Van Loosdrecht, M. C.

(13) Desloover, J.; De Clippeleir, H.; Boeckx, P.; Du Laing, G.; Colsen, J.; Verstraete, W.; Vlaeminck, S. E. Floc- 